\title{
Targets of Violence: Evidence from India's Naxalite Conflict
}

\author{
Oliver Vanden Eynde* \\ Job Market Paper
}

15 November 2011

\begin{abstract}
Insurgents in civil conflict typically target both government forces and civilians. This paper examines a rebel group's strategic choices of its targets and the intensity of violence. In a simple theoretical framework, negative labour income shocks are predicted to: (i) increase violence against civilians to prevent them from being recruited as police informers; and (ii) increase violence against the government through increased rebel recruitment, but only if the rebels' tax base is sufficiently independent from local labour productivity. These theoretical predictions are confirmed in the context of India's Naxalite conflict between 2005 and 2010. Exploiting variation in annual rainfall in a panel of district-level casualty numbers, I find that negative rainfall shocks: (i) increase Maoist violence against civilians; (ii) increase Maoist violence against security forces, but only in those districts in which the Maoists have access to key mineral resources.
\end{abstract}

Keywords: Conflict, Violence against Civilians, Organisation of Rebel Groups, Maoist Rebels in India, Income Shocks, Natural Resources.

\section{Introduction}

The cost of civil war is to a large extent borne by the non-combatant population. The civilian population does not just suffer from the indirect or unintentional consequences of war. In most conflicts, insurgents devote considerable effort to targeted attacks on civilians. Understanding the specific logic of different types of violence is crucial for the design of effective conflict resolution policies. A particular concern is that policies that aim to weaken the insurgents' fighting capacity against the government could come at the cost of inciting targeted violence

${ }^{*}$ London School of Economics and Political Science (STICERD and EOPP), email: o.w.vandeneynde@lse.ac.uk. I am grateful to Gerard Padro i Miquel and Robin Burgess for their support and advice throughout this project. I would also like to thank Jean-Paul Azam, Tim Besley, Maitreesh Ghatak, Stephen Haber, Radha Iyengar, Sandip Mitra, Torsten Persson, and Yona Rubinstein for helpful comments and discussions. I also benefited from comments by seminar participants at LSE, Sussex, Warwick, NEUDC 2011, and the Lisbon Meeting on Institutions and Political Economy. Support from a Bagri Fellowship (Asia Research Centre, LSE) is gratefully acknowledged. All remaining errors are mine. 
against civilians. This paper tries to uncover the drivers of targeted violence against civilians. To this end, I develop a simple theoretical framework that links the targeting decisions of a rebel group to labour income shocks. I subsequently exploit exogenous variation in rainfall to test the predictions of this framework in the context of India's Naxalite conflict. My findings suggest that rebels strategically choose the intensity of violence against civilians in order to deter civilian collaboration with the government. Moreover, I argue that the structure of the rebels' tax base determines whether a rebel group can exploit negative income shocks to boost its fighting capacity against the government.

Violence against civilians could serve many purposes. This paper highlights the role of civilian collaboration. I develop a theoretical framework that describes a rebel group's strategic choice of how to allocate its fighters. In the short run, the key objective of the rebels is to challenge the government. This enables them to promote their long term goals of control over territory and future economic rents. However, rebels must also confront the reality that civilians may act as police informants, thus restraining their capacity to attack the government. By staging targeted attacks against informers, the rebels can limit the incentive of civilians to help the government. As the rebel group manages a limited number of fighters, it needs to allocate its cadres strategically between either of these two activities: (i) direct assaults on government troops, (ii) or the exercise of control over the civilian population. How a rebel group manages its personnel depends on the economic environment. I assume that the rebels need to tax the local economy to compensate their recruits. In contrast, the government does not rely on local economic conditions to fund its payments to informers. In this sense, the conflict is characterised by asymmetric taxation capacity.

What happens to rebel violence if a negative labour income shock hits a local conflict zone? As the government's tax base and the corresponding budget for paying informants is exogenous to local economic conditions, the negative labour income shock increases the willingness of the population to share information with the government. In response, the rebel group finds it optimal to boost the number of rebels devoted to targeting informants in order to deter collaboration. However, the rebel group's need to shift resources towards controlling the population comes at the expense of reducing its fighting capacity against the government. The extent to which the rebels can maintain direct fighting capacity now depends on the rebels' local tax base. If the rebels mainly rely on taxation of the local labour market, a negative income shock will hurt their tax base and they will not be able to boost recruitment. Only if the rebel group has access to sources funding that are not correlated with local labour productivity, will it be able to exploit a negative labour income shock to boost its recruitment and thus stage more attacks against security forces. My paper tests these predictions for a conflict that is of major concern to policy makers: India's Naxalite conflict.

India's Naxalite movement has been described by the Indian Prime Minister Manmohan 
Singh as "the single biggest internal security challenge ever faced by our country". ${ }^{1}$ The conflict claimed at least 4,800 lives over the 2005-2010 period. India's Naxalite conflict provides an ideal testing ground for the theoretical predictions of this paper for a number of reasons. First, the Naxalite conflict has seen high levels of targeted violence against civilians, who account for more than one third of the total number of casualties. Second, due to the reliance of the Naxalite affected areas on rain-fed agriculture, exogenous variation in rainfall can be exploited to identify the impact of labour productivity shocks on the intensity of violence. Third, the Naxalite conflict affects a large number of districts and its actors have asymmetric financial capacities. Observers indicate that the rebels heavily rely on taxation of the local economy, whereas the government relies on a much broader tax base. Interestingly, the Naxalites operate in areas that include (but are not limited to) districts that produce key mineral resources. These mineral resources should make the rebels' local tax base more independent from local agricultural labour market conditions. Hence, variation in mineral resource wealth can be used to identify the differential impact of labour income shocks on violence, as required by the theoretical framework.

To test the predictions of the theoretical framework, I collect a data set of annual casualty numbers at the district level between 2005 and 2010. These conflict outcomes are combined with Kharif season rainfall data, data on mineral resource wealth, and key socio-economic and environmental controls. Importantly, the data set allows for casualties to be attributed to three categories: civilians, security forces, and Maoists. In support of the subsequent reduced form approach, I first confirm that negative rainfall shocks lead to lower rice production in the region under study. This finding supports the interpretation of rainfall shocks as determinants of agricultural income in this context.

The key result of this paper is that lower Kharif rainfall boosts Naxalite violence against civilians, regardless of the resource environment. This finding is consistent with the idea that rebels use violence against civilians to counterbalance the increased appeal of collaboration after scanty rainfall. For security force casualties, I find that violence only increases in response to negative rainfall shocks in those areas that produce key minerals. This finding is consistent with the idea that the rebels can only use a negative income shock to boost recruitment (and thus their fighting capacity against the government), if their tax base does not depend too much on local labour productivity. To shed further light on the mechanism that underlies these results, I use detailed incident information to break down civilian casualties into three groups: civilian collaborators; other civilian targets; and civilians who were not the intended target of the attack. In support of the mechanism highlighted by this paper, I confirm that my results are driven by targeted attacks on civilian collaborators. Strikingly, the results on untargeted civilian casualties follow exactly the same pattern as those for security force casualties: a negative rainfall shock boosts violence, but only in mining districts. Furthermore, the main

\footnotetext{
${ }^{1}$ Economist, 25 Feb 2010, "Ending the Red Terror".
} 
results survive a variety of robustness checks, including (a) controlling for other variables that could explain the differential impact of income shocks in mineral rich areas; (b) relying on alternative measures of mineral resource wealth; (c) using an alternative rainfall shock measure; (d) comparing the baseline results from a Poisson model to OLS results.

The results of this paper shed light on the drivers of targeted violence, by highlighting both the role of civilian collaboration and the importance of the rebels' tax base. These insights matter for the design of conflict resolution strategies. By offering rewards that are conditional on collaboration, the government may want to exploit negative income shocks to boost collaboration and weaken insurgents. My results suggest that this strategy could mainly put civilians at risk of retaliation, as the rebels can strategically respond by boosting violence against civilians.

This paper brings together recent work on the role of income shocks in conflict and research on the logic of violence against civilians. A growing body of research explores the targeting of the non-combatant population in civil conflict. The mechanism highlighted in this paper is close to the work of Kalyvas (2006), who analyses in detail how civilian collaboration relates to selective violence. ${ }^{2}$ Berman, Felter and Shapiro (2011) also consider the strategic interaction between governments, civilians, and rebels. These authors develop a model of retaliatory violence that is close to the framework presented in this paper, but they do not provide empirical evidence on such violence. The existing empirical evidence on targeted violence against civilians is mainly based on case studies and cross-sectional regressions. ${ }^{3}$ This paper is one of the first empirical contributions to explore the causes of variation in targeted violence against civilians versus the government in a subnational panel. In contrast to the existing literature, this paper explicitly links targeted violence against civilians to labour income shocks. This approach enables me to overcome key endogeneity concerns.

Several key contributions in the conflict literature share the focus of my paper on labour income shocks. Dube and Vargas (2011) show that a fall in coffee prices led to increased violence in the Colombian civil war. Miguel, Satyanath, and Sergenti (2004) find that negative GDP shocks, as instrumented by rainfall growth, explain the onset of civil wars in Sub Saharan Africa. ${ }^{4}$ Most of the theoretical arguments that link labour income shocks to violence rely

\footnotetext{
${ }^{2}$ Kalyvas (2006) argues that selective violence against civilians is highest in areas with asymmetric, but incomplete control by the rivalling parties.

${ }^{3}$ Weinstein (2007) also highlights the role of selective violence against civilian collaborators. Ballcels (2010) considers direct violence against civilians in conventional civil wars. She finds a positive relationship between selective killings of civilians in the Spanish Civil War and pre-war political competition. In an alternative approach, Azam (2006) argues that violence against civilians could be driven by strategic looting that aims at lowering the opportunity cost of participation in conflict. Azam and Hoeffler (2002) highlight that violence against civilians could also be motivated by military objectives. Humphreys and Weinstein (2006) argue that rebels who are driven by material incentives are more likely to abuse civilians in comparison to units which share common goals and have a strong command structure. The role of mineral resources is developed in more detail by Weinstein (2005), who argues that mineral resource wealth leads to opportunistic rebellions. Further empirical work on violence against civilians includes Eck and Hultman (2007) and Restrepo and Spagat (2004).

${ }^{4}$ Besley and Persson (2010) confirm these findings for a wider range of income shocks and for a larger set
} 
on the idea that negative shocks reduce the opportunity cost of joining armed conflict. ${ }^{5}$ However, this view has been challenged in recent work by Berman, Callen, Felter and Shapiro (2011). These authors find that high unemployment is associated with reduced violence in the context of Afghanistan, Iraq, and the Philippines. They argue that high unemployment could mainly facilitate information gathering by counterinsurgency forces. My paper suggests that the relationship between labour income shocks and violence against the government crucially depends on the structure of the rebel's tax base. For the opportunity cost channel to dominate in response to a negative labour income shock, the rebels need access to external sources of funding. Therefore, my analysis can account for the conflicting findings on the relationship between income shocks and violence in the existing literature.

Finally, this paper aims to contribute to the understanding of India's Naxalite insurgency. It is well established that civil conflict hampers economic development, and previous work has suggested that the Naxalite conflict has indeed reduced economic growth in the affected states. ${ }^{6}$ This consideration gains even more relevance because the districts affected by Naxalism are among India's poorest regions. ${ }^{7}$ Given the particular developmental challenges faced by India's so-called "Red Corridor", the importance of understanding the logic of Naxalite violence can hardly be overstated. While existing work points at factors that explain the susceptibility of districts to Naxalite activity in the long run, these studies cannot account for the variation in the intensity of different types of conflict over time. However, understanding the dynamics of conflict and the strategic behaviour of its parties is crucial for the design of effective conflict resolution strategies. This paper is the first contribution to explore the causes of changes in the intensity of Naxalite violence within districts over time. It is also the first study to highlight the logic of Naxalite violence against civilians.

The paper is organised as follows. First, I present a simple model that generates predictions regarding the impact of labour productivity shocks on different types of violence. Second, I discuss the background of the Naxalite conflict. Third, I describe the data used in this study. Fourth, I discuss the empirical strategy. Fifth, I discuss the main findings and I present key robustness checks. In the final section, I offer concluding remarks.

of countries. Iyengar, Monten, and Hanson (2011) find that higher spending on employment programmes by the US military reduced labour-intensive insurgent violence in Iraq. Blattman and Miguel (2010) survey the broader conflict literature. Ross (2004) provides a survey of the literature on the relationship between civil war and natural resources (e.g. Collier and Hoeffler, 2000; and Elbadawi and Sambanis, 2000).

${ }^{5}$ See for example Chassang and Padro i Miquel (2009); Dal Bó and Dal Bó (2011).

${ }^{6}$ Collier and Hoeffler (2007), and Blattman and Miguel (2010) survey the extensive empirical literature on the consequences of conflict. Nilakantan and Singhal (2011) put the economic cost of India's Naxalite conflict at $12 \%$ of the state level economic output.

${ }^{7}$ Borooah (2008). Banerjee and Iyer (2005) suggest that the so-called "Red Corridor" of severely affected districts may owe its poor living standards to a colonial legacy of underinvestment in agriculture. In the context of Nepal's Maoist rebellion, the intensity of violence has also been linked to poverty (Murshed and Gates, 2007; Do and Iyer, 2008). Focusing on the same conflict, Macours (2008) finds that rebel recruitment through abduction was more intensive in Nepalese districts that experienced fast growth in income inequality. 


\section{Theoretical framework}

In this section, I present a simple, reduced form model that links labour productivity shocks to the strategic deployment of rebels against civilian or government targets. ${ }^{8}$ The model presented here combines key elements from four recent models in the insurgency literature. It includes (1) a rebel group budget constraint (as in Dal Bó and Dal Bó, 2011), (2) information provision by civilians and the possibility of retaliation by the rebel group (as in Berman et al., 2011b), (3) asymmetric taxation capacity (as in Besley and Persson, 2011), and (4) the strategic allocation of rebels (as in Azam, 2006).

First, the model describes the market for rebels. Rebels tax the economy and their income is given by:

$$
B=p[\theta(L-F)+R]
$$

This revenue function assumes that a fixed fraction $p$ of economic output is collected as a "tax" (or looted) by the rebels. Total agricultural output is given by $\theta(L-F)$, in which $F$ indicates the number of people fighting for the rebels, and $L$ stands for the total labour endowment in the economy. $\theta$ denotes labour productivity in a linear production function, while $R$ stands for an alternative source of funding that does not depend on agricultural productivity, e.g. natural resources. The rebel group uses its income to pay fighters. It is assumed that their total income is divided equally among the rebels, so that the rebel wage equals $\frac{B}{F}$. As fighters are drawn from the agricultural sector, their reservation wage is equal to the agricultural output they forgo: $(1-p) \theta$. The participation constraint requires that the wage paid by the rebel group is higher than the reservation wage. In the labour market equilibrium, this condition holds with equality:

$$
\frac{p}{F}[\theta(L-F)+R]=(1-p) \theta
$$

This condition implies that the returns to agricultural work equal the returns to becoming a rebel. ${ }^{9}$ This equilibrium condition can be rewritten as:

$$
F=p L+p \frac{R}{\theta}
$$

The second market considered by the theoretical framework is the market for informants.

\footnotetext{
${ }^{8}$ The appendix discusses a re-interpretation and extension of the simple model presented here. This extension further microfounds the use of violence against civilians.

${ }^{9}$ The condition corresponds a simplified version of the appropriation model proposed by Dal Bó and Dal Bó (2011). However, I do not directly equate appropriation to violence. The assumption that $p$ is a fixed fraction of output simplifies the analysis. The model can incorporate a general appropriation function $p(F)$ without changing the results qualitatively. However, additional assumptions on the form of the cost function $C(\tau F, \theta(1-p))$ are needed to guarantee the existence of a fixed point in proposition 3 .
} 
It is assumed that a certain share of the population, which could include both fighters and civilians, exogenously receives valuable information. Therefore, they can be hired to act as informants for the government. Informants receive payments $X$ that are not responsive to labour productivity. ${ }^{10}$ This assumption reflects the asymmetric nature of the conflict: the government's tax base is assumed to be independent from local economic conditions. ${ }^{11}$ However, informed individuals face a cost if they decide to collaborate with the government. Importantly, the cost is assumed to be increasing in labour productivity. There are two main justifications for this assumption. First, citizens must devote time to inform the government, which may hamper their productive capacity. Second, the rebel group may destroy the economic output of citizens in retaliation for passing on information. ${ }^{12}$ These two channels could reinforce each other: the threat of retaliation may force informants to hide and to give up economic production. Higher retaliation capacity may also increase the share of output destroyed by rebels. These relationships are captured by the cost function $C(\tau F, \theta(1-p))$. The cost function includes the retaliation capacity $\tau F$ as its first argument. $\tau$ stands for the fraction of rebels who are employed to control and monitor the population $(0 \leqslant \tau \leqslant 1) .{ }^{13}$ In this function, it is assumed that $C_{1}>0, C_{2}>0, C_{1,2} \geqslant 0$. The timing of the game is such that the potential informants move after the rebel group. The decision to provide information is based on observed $\tau F$ and $\theta$. The returns to providing information to the government can now be described as follows:

$$
i[X-C(\tau F, \theta(1-p))]
$$

The decision of the informed population to collaborate with the government is denoted by $i=1, i \in\{0,1\}$. The optimal decision rule of the informed population is now given by: ${ }^{14}$

\footnotetext{
${ }^{10}$ Counter-insurgency methods can be brutal (Weinstein, 2007, p.6). To capture this idea, $X$ could also include non-punishment by the government. Similarly, the rebels could offer rewards for collaboration. The crucial assumption of the model is that the appeal of collaboration with the government is decreasing in $\theta$. This assumption is credible if the government has access to a budget that is independent from local economic conditions or if the rebels are less constrained in their capacity to destroy the output of informers.

${ }^{11}$ The government is non-strategic in this simplified model. There could be multiple justifications for this assumption. In line with the asymmetric setting of my framework, the government could take strategic decisions (i.e. the choice of $X$ ) at a level that is higher than the local conflict zone considered by the model. Alternatively, if the government and the rebel group move simultaneously, there could be competition over informers (in which rebels match higher rewards with higher intimidation). In the equilibrium, the rewards offered by government could be limited by its budgetary capacity or its willingness to pay for information (which are independent from $\theta$ ).

${ }^{12}$ The timing of the game, which will be introduced below, is only fully consistent with the second interpretation. The timing can be altered to incorporate the first interpretation without changing the results.

${ }^{13}$ In the appendix (A.1.2.), I discuss a model in which the population does not directly observe the investment in retaliation capacity, $\tau F$. Instead, it observes the number of non-security force killings by the rebel group, which is a monotonically increasing function of $\tau F: K(\tau F) . \quad K(\tau F)$ reveals the minimum investment in retaliation capacity. This extension microfounds the targeting of civilians.

${ }^{14}$ In principle, the returns to becoming an informant should enter the labour market condition in equation (1). However, there are two justifications for treating this market separately (apart from the simplification of the analysis). First, under the assumption that the costs of becoming an informant do not depend on rebel
} 


$$
i^{*}=1 \Leftrightarrow X>C(\tau F, \theta(1-p))
$$

Finally, the rebel group strategically chooses how to allocate its fighters. The objective function is increasing in the number of fighters who are not involved in controlling the population. These are the fighters whom the rebel group can use to achieve its long-term goals, such as the control of territory or future sources of income. ${ }^{15}$ These rebels have the capacity to carry out direct attacks on the government (i.e. the security forces). However, it is assumed that the capacity of the rebels to attack the government disappears if the informed population decides to share its information with the government. This is captured by the following objective function:

$$
W(\tau)=\left(1-i^{*}(\tau F)\right)(1-\tau) F
$$

The timing of the game is as follows:

1. Production and appropriation take place according to equation 1.

2. The rebel group chooses $\tau F$.

3. The informed population decides whether to provide information: $i \in\{0,1\}$.

4. The pay-offs are realised:

- For the rebel group: $W=(1-i)(1-\tau) F$

- For the informed population: $U^{i}=(1-p) \theta+i(X-C(\tau F, \theta(1-p)))$

- For all other individuals: $U=(1-p) \theta$

The model is solved by backward induction, as the rebels maximise their objective function with respect to $\tau$ in anticipation of the informers' reaction. It can be seen immediately from the discontinuous objective function that the rebel group optimally chooses $\tau$ such that the returns to becoming an informant (expression 6) equal zero.

Proposition 1: In the Subgame Perfect Equilibrium, the rebel group sets $\tau^{*}$ such that individuals are indifferent between working as informants or not. The informants choose $i^{*}=1$ if $\tau<\tau^{*}$ and $i^{*}=0$ if $\tau \geqslant \tau^{*}$.

status, the returns to becoming an informant would be added to both the rebel wage and the agricultural wage and would not affect the equilibrium condition. Second, there are no opportunistic informants in equilibrium as long as $F$ is sufficiently large. Therefore, the functions describing the rebel market could account for the impact of the informants' decisions without altering the equilibrium results.

${ }^{15}$ The idea that the rebel group has long term goals for which it needs to recruit fighters is also central to Berman et al. (2009 and 2011) and Azam (2006). 
The following propositions describe the comparative statics of the allocation of fighters with respect to productivity shocks.

Proposition 2: For $R=0$, a productivity shock does not affect the size of the rebel group. A negative productivity shock increases the number of rebels engaged in controlling civilians $\left(\frac{\partial \tau^{*} F}{\partial \theta}<0\right)$. A negative productivity shock decreases the number of rebels engaged in conflict with the government $\left(\frac{\partial\left(1-\tau^{*}\right) F}{\partial \theta}>0\right)$.

Proposition 3: For $R>0$, a negative productivity shock increases the size of the rebel group. A negative productivity shock increases the number of rebels engaged in controlling civilians $\left(\frac{\partial \tau^{*} F}{\partial \theta}<0\right)$. A negative productivity shock can lead either to an increase or a decrease in the number of recruits fighting the government. There exists an $\bar{R}$ such that for $R<\bar{R}, \frac{\partial\left(1-\tau^{*}\right) F}{\partial \theta}>0$ and for $R>\bar{R}, \frac{\partial\left(1-\tau^{*}\right) F}{\partial \theta}<0$.

Proof See Appendix.

It seems reasonable to assume that violence against civilians is increasing in the number of rebels who control the civilian population $\left(\tau^{*} F\right)$, whereas violence against the government is increasing to the number of rebels who can focus on insurgency activities, $\left(1-\tau^{*}\right) F$. Under these assumptions, the model yields easily testable predictions. First, violence against civilians is negatively associated with productivity shocks, regardless of the resource environment. Violence against the government should be increasing in productivity, unless the rebel group has access to fixed sources of funding that do not depend on local labour market economic conditions (e.g., mineral wealth). In that case, the rebel group can exploit a negative productivity shock to boost recruitment and stage more attacks. These predictions are tested in the context of India's Naxalite conflict. ${ }^{16}$

\section{$3 \quad$ Background}

This section briefly sketches the background of India's Naxalite conflict. First, I will offer a brief history of this conflict. Second, I put forward arguments for why India's Naxalite conflict provides an interesting testing ground for the hypotheses that were derived from the theoretical framework.

\subsection{Brief history}

India's Naxalites owe their name to a small village in rural West Bengal, "Naxalbari", from which the movement has steadily spread since 1967. The Naxalbari uprising was triggered by the attack on a tribal villager by local landlords. The resulting movement gained the

\footnotetext{
${ }^{16}$ The fact that $F$ does not depend on $\theta$ in the absence of $R$ is also a reformulation of Fearon's findings (Fearon, 2005).
} 
support from key members of the Communist Party of India (Marxist), which did not prevent the $\mathrm{CPI}(\mathrm{M})$ from brutally repressing the peasant revolt in Naxalbari. The sympathisers of the uprising formed the All India Coordination Committee of Communist Revolutionaries (AICCCR), which promoted the "Allegiance to the armed struggle and non-participation in elections". Until today, these elements remain the corner stones of the Naxalite movement. The 1970-2000 period was marked by a high level of conflict between different Naxalite groups. However, in 2003, the two major Naxalite outlets that were committed to violent struggle merged to form the Communist Party of India (Maoist). This merger is believed to be one of the drivers of the recent growth in Naxalite violence (Kujur, 2009). The declared goal of the present CPI (Maoist) is to overthrow the Indian state through armed struggle and to establish a liberated zone in the centre of India. ${ }^{17}$ In 2006 , the Naxalite movement was famously described by the Indian Prime Minister Manmohan Singh as "the single biggest internal security challenge ever faced by our country". ${ }^{18}$ The number of districts that were "severely affected" by Naxalite activity increased from 51 districts to 62 districts over the period 2005-2007. ${ }^{19}$ The continuing popularity and strength of the Naxalite movement is perceived to stem from chronic underdevelopment in the affected communities (Borooah, 2008). The Naxalites are also thought to be banking on the grievances of the tribal population against mining activity, which has led to large-scale displacement in certain Maoist strongholds (Kujur, 2009).

Over the 2005-2010 period, the Naxalite's activities included the sabotage of government infrastructure (e.g. schools that can be used as polling booths, Gram Panchayat buildings, telecommunication towers) in efforts to increase their political control. The Maoists also staged highly visible attacks against the government's security forces. On 15 February 2010, a group of Naxalite rebels killed 24 Bengali policemen. A surprisingly large number of attacks also affect the civilian population, which accounts for more than one third of the total number of casualties (including Maoist and police deaths) in the 2005-2010 period (SATP Timelines).

The Government's response to the Naxalite conflict has been characterised by a lack of coherent strategy between successive governments and different levels of administration (Kujur, 2009). While most states could not stop the recent surge in Maoist activity, Andhra Pradesh is often credited for pursuing a successful combination of targeted development policies and the deployment of a specialised police force ("Greyhounds"). ${ }^{20}$ Other states rely on a combination of state police forces and Central Reserve Forces (which are raised at the national level) to contain Naxalite activity. ${ }^{21}$ Certain states are also thought to support semi-legal

\footnotetext{
${ }^{17}$ This section is based on Kujur (2008) who provides a detailed overview of the organisational history of India's Maoist organisations.

${ }^{18}$ Economist, 25 Feb 2010, "Ending the Red Terror".

${ }^{19}$ http://www.satp.org/satporgtp/countries/india/database/conflictmap.htm.

${ }^{20}$ Nilakantan and Singhal (2011).

${ }^{21}$ The Economist, 2010 (http://www.economist.com/node/15869400).
} 
militant groups (such as Salwa Judum) in response to the Naxalite threat. While the Indian Government has historically treated the Naxalite insurgency as a "Law and Order" issue, it has not completely ignored the economic conditions that are thought to constitute the basis of the conflict. Naxalite affected districts qualify for several sources of central Government funding for development purposes, some of which are specific to Naxalite regions and some of which (including NREGA) ${ }^{22}$ were rolled out at a national level. However, the extent to which districts make use of these funds depends on the political capability of the state Governments (Kujur, 2009).

\subsection{Key characteristics}

There are several reasons for why the Naxalite conflict provides an ideal testing ground for the theoretical arguments set out in the theoretical framework.

First, information is important in this conflict. Maoists and the Government clearly compete for civilian collaboration. While certain officials deny the existence of informers ${ }^{23}$ (possibly in an attempt to protect civilians from reprisals), the Government openly offers substantial rewards for tip-offs that lead to the death or arrest of Maoists. ${ }^{24}$ Certain state governments (possibly with the support of the Centre) are thought to have encouraged civilians to join militant groups that help the police to collect information and assist them in operations. Finally, the state governments have also rolled out several programmes to encourage low ranking Maoists to surrender and provide information. ${ }^{25}$ In line with the theoretical framework, the Naxalite groups react to these attempts to elicit collaboration (or desertion) by explicitly threatening to kill or destroy the property of police informers:

"The CPI-Maoist reportedly issued a press release at Chintapalli village in the Visakhapatnam District, blaming the Police for turning the Girijans (local tribals) into informers by spending huge amounts of money and warned that the properties acquired by the surrendered Maoists, after taking up the job of Home Guard, would be destroyed.[...]" (SATP Timelines, Andhra Pradesh, 2007)

When the Maoists resort to violence against civilians, their punishments tend to be highly visible and brutal:

\footnotetext{
22 "The Mahatma Gandhi National Rural Employment Guarantee Act aims at enhancing the livelihood security of people in rural areas by guaranteeing hundred days of wage-employment in a financial year to a rural household whose adult members volunteer to do unskilled manual work." (NREGA, 2011, http://nrega.nic.in/netnrega/home.aspx)

${ }^{23}$ Director General of Police, quoted in SATP Timelines, Orissa (2009).

24 "Times of India reported that the Andhra Pradesh Police have included 650 new names to its hit-list of 1,200 Maoists. [...] The State has increased the reward amount on all these wanted Maoists and their leaders by nearly INR 162 million." (SATP Timelines, Andhra Pradesh, 2007)

25 "Maharashtra Government announces an amnesty scheme for the Maoists. Those surrendering will be given a 'cash prize' immediately [...]." (SATP Timelines, Maharashtra, 2005)
} 
"CPI-Maoist cadres killed two people, including a village head, at a [kangaroo court] in Jamui District after finding them "guilty" of helping the Police. Reports said that a group of armed Maoists killed Babuli village head Ashok Das and his close associate [...]. "Their throat was slit by Maoists to send a message of harsh punishment to others," informed the Police." (SATP Timelines, Bihar, 2008)

A second key characteristic of the Naxalite conflict is its asymmetric nature. The theoretical framework clearly assumes asymmetric reliance on local labour productivity. This assumption seems reasonable for a large number of intra-state conflicts, including the Naxalite insurgency. The last quote (referring to "huge amounts spent on informers") reflects the fact that the Government (both at the state and the Union level) can draw from a large and stable tax base to fund anti-Maoist operations. Moreover, counter-insurgency strategies are In contrast, the Naxalites need to tax local economic activity (and agricultural output in particular) to fund their activities: ${ }^{26}$

"ANI reports that the CPI-Maoist is collecting INR 10,000 from each farmer as 'tax' in the Jamatara District. The farmers are being forced either to pay up or to stop tilling their fields." (SATP Timeline, Bihar, 2005)

A third characteristic of the Naxalite conflict is that mineral resources are an important component of the Naxalite's tax base in certain districts. On 20 May 2010, the Maharashtra State Home Minister R. R. Patil openly accused the mining industry of funding Left Wing Extremists (LWEs). ${ }^{27}$ Newspaper reports provide anecdotal evidence on the modus operandi of the Naxals:

"Early last year, the Maoists blasted pipelines of a leading steel company cutting through Chitrakonda in Malkangiri district. Within a month, the company's infrastructure in the same place was targeted again. A guest house was set ablaze. A pump house, control room and property worth several lakhs of rupees were damaged. Then the attacks stopped. Police sources said this happened only after Rs 2 crore went into the Maoist purse. Illegal mining in states such as Orissa and Jharkhand is a rich source of revenue for the Maoists." (Times of India, 2011)

In conclusion, civilian collaboration is important in this conflict, the tax bases of the Government and the rebels are asymmetric, the rebels need to tax agricultural activity, but mineral resources provide variation in the structure of the rebels' tax base within this conflict. Hence, this setting offers an ideal testing ground for the hypotheses that were set out in the theoretical framework.

\footnotetext{
${ }^{26}$ Srivastava (2009), and Times of India, 2011, (http://timesofindia.indiatimes.com/india/ Extortnomics-Maoists-raise-Rs-2000-crore-every-year/articleshow/7498493.cms).

${ }^{27}$ Source: SATP 2010 Timeline. See also Srivastava (2009) and The Economist (25 February 2010) for similar claims (http://www.economist.com/node/15580130).
} 


\section{Data}

This paper relies on violence data from the South Asia Terrorism Portal (SATP). ${ }^{28}$ The SATP combines newspaper reports on Naxalite activity into daily incident summaries. These summaries typically provide the district (and sometimes village) in which the incident took place and the number of casualties on each side of the conflict (civilians, Maoists and security forces). Based on this information, I construct variables for the number of casualties, for three categories (civilian, security forces and Maoists) at the district-year level. ${ }^{29}$ The analysis will be restricted to those states that are confronted with significant Naxalite activity over the period under study. ${ }^{30}$ One limitation of this dataset is that it does not systematically include casualties who do not immediately succumb to their injuries. An additional limitation is that the number of Maoists casualties is hard to verify and the reports often highlight that these numbers are based on police sources. ${ }^{31}$ One can imagine that security forces have an incentive to overstate the number of Maoists they killed or to include innocent civilians who are wrongfully targeted in police actions. These concerns are addressed to some extent by the police policy of disclosing the names and the ranks of any killed Maoists to add credibility to its reports. ${ }^{32}$ Unfortunately, the data-set does not include state violence directed towards civilians, in spite of wide-spread claims of atrocities being committed by state forces. Of the three types of violence reported in the dataset, Maoist violence is probably the most prone to errors. However, none of the key results are based on this variable. With regards to civilian casualties, it is possible that news on Maoist violence does not reach newspapers if it occurs in isolated communities. Civilian casualties only include deaths thought to be inflicted by Maoists, although it cannot be ruled out that some casualties are wrongfully attributed to the Maoists. The type of casualties which is probably the least prone to misreporting are government casualties, as these are highly visible. Again, these casualties only include deaths inflicted by Maoist groups.

Data on mineral output are obtained from the ministry of Labour and Employment. ${ }^{33}$ I focus on three minerals which are linked to Maoist activity in the SATP incident lists: iron, bauxite and coal. For iron and bauxite, I rely on production data from 2005-2006. For coal,

\footnotetext{
${ }^{28}$ www.satp.org, accessed in January 2011.

${ }^{29}$ The data are drawn from three sources which partially overlap: "Fatalities and Incidents of Landmine Explosion by Maoists: 2005-2010"; State Incident Timelines (2005-2010); Major Incidents. To code the large volume of entries in these timelines, key words (death, killed, injured, etc.) were used to identify relevant entries. The reliance on three different data sources further limits the risk of failing to identify incidents which involve casualties.

${ }^{30}$ Andhra Pradesh, Bihar, Chhattisghar, Jharkhand, Karnataka, Maharashtra, Orissa and West Bengal. These states are located on a map of India in figure1.

${ }^{31}$ Reports often indicate that maoists drag bodies of killed fighters away to prevent the police from capturing the body.

${ }^{32}$ Also, Maoist casualties include certain casualties that are inflicted by Maoist groups among themselves or by civilian groups, even though such events appear to account for a small fraction of the entries.

${ }^{33}$ These data are available from www.indiastat.com.
} 
production data from 2003 are used. To reduce endogeneity, these minerals are evaluated at India-wide 2004-2005 prices. ${ }^{34}$ The use of iron and bauxite data for years after the baseline may still give rise to endogeneity concerns if production responds to violence. Furthermore, Naxalite extortion is often linked to illegal mining activity, which could depress the official output data in affected districts. These concerns are addressed by reporting key results for mineral production dummies (which should not capture any endogenous output responses on the intensive margin) and for an alternative measure of mineral production. ${ }^{35}$

Rainfall data were collected from the Indian Meteorological Department (IMD), for the years 2004-2010. For several districts, rainfall data is not available, in particular for nonmonsoon months. To address this problem I restrict my analysis to rainfall in the main monsoon season (June-September). This approach has the additional advantage of focusing on rainfall shocks that are directly linked to the main crop growing season, while rainfall outside of the growing season could have more ambiguous effects on agricultural productivity. Monsoon rice (Kharif rice) accounts for the bulk of the rice production in the region under study (Prasad, 2006). To deal with missing rainfall data in the Kharif months, I will merge districts as described below.

To confirm the validity of the use of rainfall, annual rice production data were collected for the period 2003-2007 from the Indian Department of Agriculture. ${ }^{36}$ These production data correspond to fiscal years (e.g. 1 April 2003- 1 March 2004) and are assigned to the earliest calendar year. This creates the maximum overlap with the fiscal year and it ensures that the main harvesting season during any given fiscal year is assigned to the calendar year in which the crops were fed. Due to missing observations, the resulting rice production panel is unbalanced and incomplete.

As additional controls, I collect 2001 census data at the district level on population, the size of the tribal population, the size of the scheduled caste population and literacy. Furthermore, I also collect forest cover and area data from the Ministry of Environment and Forest. ${ }^{37}$

As rainfall information is missing for several districts (even for monsoon months) and as certain districts were split over the 2001-2010 period, I merge districts to create a balanced panel of violence outcomes and explanatory variables. 207 districts are merged into 167 districts based on four criteria. First, 2001 census districts that were split during the 20012010 period are remerged to their 2001 boundaries. Second, districts with missing rainfall

\footnotetext{
${ }^{34}$ Prices were calculated from the value of Indian mineral production, as reported in: Ministry of Mines, 2010, "Annual Report 2009-2010", Annexure 3.1; Ministry of Mines, 2009, "Annual Report 2008-2009", Annexure 3.1. Prices are converted to real prices using the CPI (http://india.gov.in/outerwin.php?id=http://eaindustry.nic.in/).

${ }^{35}$ This alternative measure is based on the US geological survey, which restricts itself to major producers and does not provide district-level production data for coal.

${ }^{36} \mathrm{http}: / /$ dacnet.nic.in/eands/AERC.htm, accessed in March 2011. Rice production data were not available for three states (Chhattisgarh, Jharkhand, and West Bengal).

${ }^{37}$ Ministry of Environment and Forest, Govt. of India., "District-Wise Forest Cover", accessed through www.indiastat.com
} 
information are merged with the closest district that has rainfall information available (based on the distance between district capitals). ${ }^{38}$ Third, the largest urban districts (Bangalore, Kolkota and Mumbai) are dropped from the analysis. Fourth, for a small number of districts, rainfall is used of a district in a neighbouring state. ${ }^{39}$ To avoid merging districts across state borders, these observations are treated independently. The resulting data set contains a balanced panel of 167 (merged) districts. ${ }^{40}$

Table 1 provides summary statistics for key variables. In appendix A.1., maps are provided for the districts that see at least 1 casualty related to the Naxalite conflict (figure 2), the number of civilian casualties over the 2005-2010 period (figure 3), the number of security forces casualties over the same period (figure 4), and the logarithm of mineral value wealth (figure 5).

\section{$5 \quad$ Empirical strategy}

This paper investigates how agricultural productivity shocks affect different violence outcomes. The paper employs rainfall shocks as exogenous determinants of agricultural productivity. While this approach has successfully been employed for the study of violence in the context of Sub-Saharan Africa (Miguel et al., 2004), the relationship between rainfall and economic activity is not straightforward in less arid regions. Nevertheless, Burgess et al. (2011) have confirmed the importance of rainfall shocks for agricultural wages and productivity in the Indian context. ${ }^{41}$ To further confirm the validity of interpreting rainfall shocks as productivity/income shocks, I first estimate a rice production function for the states that were selected in this paper:

$$
\log \left(\text { Rice }_{i s t}\right)=\beta_{1} \operatorname{lograin}_{i s t}+\mu_{i s}+\theta_{s t}+\phi_{M t}+\varepsilon_{i s t}
$$

\footnotetext{
${ }^{38}$ The mergers on the basis of the first two criteria are summarised in the form "original district (merged district)". Nalgonda (Hyderabad), Banka (Baghalpur), Arwal (Patna), Begusarai (Khagaria), Gaya (Aurangabad), Gopalganj (Siwan), Jamui (Munger), Kaimur (Rohtas), Jahanabad (Patna), Nalanda (Patna), Nawada (Patna), Saran (Bhojpur), Sheikhpura (Munger), Sheohar (Sitamarhi), Sapaul (Saharsa), Vaishali (Patna), Bokaro (Dhanbad), Chatra (Hazaribagh), Dumka (Deoghar), Garhwa (Palamu), Godda (Deoghar), Jamtara (Deoghar), Khuti (Ranchi), Kodarma (Hazaribagh), Latehar (Palamu), Lohardaga (Ranchi), Pakaur (Maldah West-Bengal), Saraikela (Purbi Singhbhum), Simdega (Gumla), Barddhaman (Nadia), WestMidnapore (Medinipur), Bargarh (Sambalpur), Bhadrak (Jajapur), Baudh (Sonapur), Kendrapara (Jagatsinghapur), Nabarangapur (Koraput), Hingoli (Washim).

${ }^{39}$ This is the case for: Gumla Jharkhand (Jashpur, Chhattisgarh); Kishanganj Bihar (West Dinajpur, WestBengal); Pakaur Jharkhand (Maldah, West-Bengal).

${ }^{40}$ I confirmed that the main results go through in the unmerged data set (results not reported).

${ }^{41}$ In an approach similar to mine, Cole et al. (2011) estimate a crop yield production function using historical Kharif season rainfall data and a wider set of crops. The authors link deviations from optimal rainfall levels to disaster relief and voter preferences. In another contribution that relies on the income effects of poor rainfall, Bholken and Sergenti (2010) explain Hindu-Muslim violence by instrumenting income growth with rainfall growth at the state level. Sekhri and Storeygard (2010) rely on the relationship between rainfall and income at the district level in their study of climate shocks and violence against women.
} 
In this equation, $\beta_{1}$ captures the elasticity of rice production with respect to rainfall. $\mu_{i s}$ is a district fixed effect. $\theta_{s t}$ and $\phi_{M t}$ respectively represent state-year fixed effects and mineral wealth-year fixed effects, which are included to make this model directly comparable to the models used in the main tables. The rice production data set is not available after 2006 and incomplete during the years for which it is available. These data limitations preclude a direct instrumentation approach or a detailed analysis of local production patterns. Nevertheless, if $\beta_{1}$ is estimated to be positive and significant, this adds credibility to the subsequent reduced form approach.

The main specification explains the number of casualties in different categories. To account for the large number of zeroes in the dependent variable, the vertical outliers in the data set, and the fact that the number of casualties is a count variable, I rely on a fixed effects Poisson Quasi-Maximum Likelihood model with robust standard errors at the district level. ${ }^{42}$ The estimated model is based on the following specification:

$$
E\left(C_{i s t}\right)=\mu_{i s} \exp \left(\beta_{1} \operatorname{lograin}_{i s, t-1}+\phi_{M t}+\nu_{s t}\right)
$$

The dependent variable $C_{i s t}$ is the number of casualties of a given type (security forces, civilians, or Maoists) for a given district $i$ in state $s$ and in time period $t$. The coefficient $\beta_{1}$ represents the elasticity of the number of casualties in district $i$ and year $t$ with respect to district rainfall in the previous year (the Kharif harvesting season is at the end of each calendar year). $\nu_{s t}$ is a state-year effect, which can account for district level policy variables that affect the number of casualties. As both economic policy and counterinsurgency strategies are devised at the state level and these policies vary widely between states (as discussed in section 2.3), $\nu_{s t}$ can account for a wide range of potentially relevant but unobserved determinants of violence. It should be noted that the district-level fixed effects $\left(\mu_{i s}\right)$ are multiplicative to rainfall shocks, which naturally makes districts with higher levels of violence more responsive to a given rainfall shock. As a result, the fixed effects effectively explain all the variation in districts that do not see any casualties and these districts do not contribute towards the estimation of $\beta_{1}$.

Equation 6 includes the first lag of the logarithm of rainfall. ${ }^{43}$ Three factors suggest that a delayed impact of rainfall shocks is appropriate for my study: (1) the timing of the harvesting season, (2) the dynamics of the conflict, (3) and concerns about direct impacts of rainfall on conflict. The harvesting season for Kharif rice is during October-December. Hence, the consumption and investment opportunities of rural households at the beginning of the calendar year will critically depend on rainfall in the previous monsoon. Moreover, Rabi crop cultivation during the dry season (November-May) is limited in the "Red Corridor",

\footnotetext{
${ }^{42}$ See Hausman et al. (1984) and Wooldridge (2002) for an introduction to this model, and see Burgess et al. (2011) for a recent application.

${ }^{43} \mathrm{I}$ include rainfall levels to account for the transitory nature of rainfall shocks (Ciccione, 2011).
} 
mainly because of underinvestment in irrigation facilities (Joshi et al., 2002). As a result, Rabi production has only limited capacity to mitigate shocks to Kharif production in this region. Moreover, successful Rabi cultivation still relies on sufficient residual soil moisture from the monsoon season (Joshi et al., 2002). As a result, scanty rainfall during the Kharif season is likely to depress both income and agricultural productivity during the next calendar year, possibly right until the next Kharif harvest. ${ }^{44}$ A second factor that suggests a delayed impact of rainfall is the conflict process itself. Increased rebel recruitment may take some time to translate into more attacks on the government, as attacks need to be planned and new recruits need to undergo training. Similarly, actual information provision (and the need for selective violence against civilians) could lag behind on the timing of becoming an informant. Finally, it is possible that contemporaneous rainfall has a direct impact on violence, apart from the income channel. In principle, rainfall shocks could make it harder (or easier) for rebels to seek refuge or stage attacks (Miguel et al., 2004). The use of lagged rainfall has the advantage of making such direct impacts less likely.

To test the hypothesis that the impact of rainfall depends on the availability of mineral resources in the district, I add additional interaction terms to equation 6. My baseline specification is now given by:

$$
E\left(C_{i s t}\right)=\mu_{i s} \exp \left(\beta_{1} \operatorname{lograin}_{i s, t-1}+\beta_{2} \operatorname{lograin}_{i s, t-1} * M_{i s}+\beta_{3} \operatorname{lograin}_{i s, t-1} * Z_{i s}+\phi_{M t}+\nu_{s t}\right)
$$

In this model, rainfall is interacted with a mineral resource wealth variable to test the hypothesis that the marginal impact of rainfall shocks is decreasing in the availability of resources. The inclusion of mineral-year fixed effects guarantees that this regression is not just picking up other effects that stem from the presence of minerals and that change over time (for instance general price shocks). Two main measures of mineral wealth will be used in the analysis: a dummy measure and a continuous variable, $\log (1+$ mineralvalue $)$.

A key endogeneity concern in equation (8) is the fact that the availability of mineral resources is not exogenous to the process that drives violence. The district-fixed effects and mineral-year fixed effects should address some of these concerns. Nevertheless, it remains possible that $\beta_{2}$ captures the differential effect of rainfall by any other variable that is correlated with the presence of mining activity. To account for this possibility, I also include interactions of rainfall with other key socio-economic variables at the district level (summarized in $Z_{i s}$ ): the proportion of the tribal population, the proportion of the scheduled caste population, the proportion of literates, the percentage of the district area covered by forests and population density.

\footnotetext{
${ }^{44}$ The impact on consumption could be even more persistent: Jharkhand's rural population faces a "hungry season" from June to October (PACS, 2009).
} 


\section{Results}

\subsection{Main findings}

The first column in table 2 confirms that rainfall shocks at the district level are positively associated with rice production. This strong relationship could reflect the limited investments in agriculture that these districts have received ever since the colonial period. ${ }^{45}$ While the rice production data do not overlap perfectly with the violence panel (as discussed in section 4), the positive relationship between rainfall and rice output supports the hypothesis that rainfall affects agricultural incomes in the region considered by this study.

The impact of contemporaneous rainfall shocks is negative but small for all three types of violence: civilian casualties, government force casualties and Maoist deaths. Based on the methodological arguments put forward earlier and on the observed delayed impact of rainfall in table 2, I focus on lagged rainfall for the remainder of the analysis. ${ }^{46}$ Rainfall shocks in the previous calendar year are found to be strongly negatively correlated with civilian casualties and deaths among the security forces. The estimated elasticities are -0.9 and -1.2 for civilian deaths and police deaths respectively. The impact on Maoist casualties is not significant. However, out of the three violence measures, this is likely to be the measure that is most prone to errors (as discussed in the data section). Moreover, police forces also have the option to arrest Maoists, which could further weaken the link between Maoist casualties and police activity. Nevertheless, the signs on Maoist casualties are consistent with an interpretation in which Maoists strengthen their position in response to negative productivity shocks, but suffer an increasing number of casualties as a result of increasing the number of attacks against the government.

Table 3 presents the baseline results. The lagged rainfall variable is interacted with a dummy for mineral production to test whether the impact of rainfall depends on the availability of mineral resources. For civilian casualties, the additional impact in mineral-rich regions is negative but insignificant. In contrast, mining districts appear to be driving the impact of rainfall on government casualties. These mining districts account for $40 \%$ of the 58 districts with at least one security force death. Strikingly, the impact of rainfall shocks is positive (albeit insignificant) in non-mining districts. This sign is consistent with the prediction from the theoretical model. The sign becomes negative in mining districts. This difference is significant at the $5 \%$ level. The addition of interactions with key (demeaned) covariates makes these effects even larger. With regards to Maoist deaths, none of the key coefficients gain significance. Table 4 repeats the analysis for a continuous measure of mineral wealth,

\footnotetext{
${ }^{45}$ In this region, British colonial policy awarded land titles in this region to land lords rather than cultivators, resulting in lower agricultural investment and public good provision (Banerjee and Iyer, 2005).

${ }^{46}$ The main results are robust to the inclusion of contemporaneous rainfall. The coefficients on contemporaneous rainfall fail to gain significance (results not reported).
} 
using $\log (1+$ mineralvalue $)$. The key results from the previous table are strengthened in this specification, suggesting that the results are not driven by districts with small mining output.

The coefficient of -1.22 on civilian casualties in table 3 indicates that for a $20 \%$ decrease in $\log$ (rainfall), ${ }^{47}$ the number of civilian casualties increases by $24 \% .{ }^{48}$ The first column suggests that the corresponding decrease in rice production is $9 \%$. The coefficients on security force casualties imply that a $20 \%$ negative shock to rainfall in a mining district increases the number of police casualties by $44 \% .{ }^{49}$ The impact of rainfall shocks on violence against the government is positive in the absence of key mineral resources, although this coefficient fails to gain significance.

As a robustness check of the main specification, I investigate the sensitivity of the main results to the choice of the econometric model. Table 9 presents OLS results for the subsample of districts that see at least one casualty of the relevant type. While the OLS results are less precisely estimated, the signs and magnitudes are consistent with the Poisson results. Moreover, a split-up of results by tertiles of the dependent variable confirms that the impacts are proportional to the level of the dependent variable. These results strongly suggest that a logarithmic model is appropriate. Table 10 confirms that the key results go through in an OLS estimation in which the dependent variable is subject to a $\log (1+x)$ transformation. ${ }^{50}$

\subsection{Interpretation}

The main results indicate that lower rainfall results in more violence directed against civilians, regardless of the presence of mineral resources. This finding is consistent with the theoretical model developed in section 2. Negative economic shocks could boost the willingness of civilians to collaborate with the government. Hence, the rebel group may find it optimal to increase its punishments of civilian collaborators or defectors in order to discourage civilians to pass on information to the government. By killing civilians in targeted attacks, the Maoists show that they have invested in sufficient retaliation capacity to locate and punish informers.

In line with this interpretation, the communication of the Maoists in the SATP Timelines underlines the importance that the Maoists attach to motivating civilian deaths. To justify attacks on civilians, the rebels often leave notes on the bodies of victims, they hold public trials, or they even contact the press directly. Moreover, they often rely on brutal execution

\footnotetext{
${ }^{47}$ A $20 \%$ shock is approximately the standard deviation of the residuals from a regression of $\log ($ rainfall) district fixed effects, state-year fixed effects and mineral-year-fixed effects. Relying on the unadjusted sample variation in $\log$ (rainfall), which is approximately $50 \%$, the estimated impact is even larger.

${ }^{48}$ This corresponds to 1 additional civilian casualties at the sample mean of 4.3 civilian casualties (conditional on the district having any civilian casualties).

${ }^{49}(44=(2.9-0.7) * 20 \%)$. At the sample mean of mining districts that have at least one police force casualty (3.7), this corresponds to 1.6 additional police deaths on average.

${ }^{50}$ Relying on the OLS specification, I confirm that the main results are robust to spatial clustering of the standard errors (reported in square brackets).
} 
methods to add further visibility to their attacks against civilians (see quote in section 3).

In tables 5 and 6 , I provide further evidence on the importance of civilian collaboration. Table 5 provides a break-down of civilian casualties by suspected motive of the killing (based on the descriptions in the SATP Timeline). For approximately $30 \%$ of casualties, a motive is not explicitly referred to. ${ }^{51}$ Focusing on casualties for whom a motive is recorded, a large majority is referred to as (suspected) collaborators. Police informers (29\%), members of mainstream political parties that oppose the Naxalites (31\%), surrendered Naxalites (2\%), and members of vigilante groups (7\%) account for a total of $69 \%$ of the casualties for which information on the motives of the attack is available. Strikingly, failure to meet extortion demands only accounts for $3 \%$ of the civilian casualties. The bulk of the remaining casualties fell victim to "untargeted attacks". These are incidents in which the civilians were not the intended target of the attack. In table 6 , the main results are shown separately for killings of civilian collaborators and victims of "untargeted attacks". In support of the mechanism highlighted in this paper, the main results appear to be driven by attacks on collaborators. In contrast, untargeted civilian killings follow exactly the pattern of security force casualties. The latter finding suggests that civilians suffer the indirect consequences of increased violence against the government. The fact that the main results are driven by targeted attacks on civilian collaborators adds further credibility to the main mechanism of this paper. Finally, there is also anecdotal evidence that illustrates how droughts affect the alliances between Naxalites and the civilian population:

"After some 30 villages in Korchi area of Gadchiroli district defied the Naxal boycott of government-run employment-generation schemes, the revolt has spread to more drought-hit villages in the region, say high-level police officials. Special Inspector General of Police (Nagpur range) Pankaj Gupta told The Indian Express yesterday that clusters of villages, gripped by a severe drought, had chosen to take on Naxalites rather than let go of an option for alternate employment. Gupta, however, didn't divulge the location of the villages which number over 20. This, he said, may prompt Naxalites to upset their plan." (Indian Express, April, 2003)

For security force casualties, the main results are consistent with the idea that the rebels' tax base shapes the relationship between labour income shocks and conflict. If the rebels' tax base is sensitive to the rainfall shocks, the rebels may not be able to exploit a negative shock to increase recruitment. This argument could explain why rainfall shocks do not lead to higher government casualties inflicted by Maoist attacks in non-mining districts. The fact that rebel groups respond to negative shocks with increased violence against the government

\footnotetext{
${ }^{51}$ The break-down of casualty numbers is based on my own coding of incidents. Most reports of casualties with "unspecified" motives strongly suggest that they are targeted attacks. Unfortunately, it is unclear which factors determine the provision of more detailed background information and there could be selection bias.
} 
in mining districts, is consistent with the interpretation that the rebel group's tax base is less reliant on agricultural output in these districts.

Underlying these interpretations are a number of implicit assumptions that may require further justification. First, I assume that the fighting capacity of the Maoists is increasing in the number of fighters deployed against the government. This assumption (which is common to most "opportunity cost" models) seems reasonable in the context of the Naxalite conflict. The SATP Timelines indicate that most Maoist attacks on the government involve a substantial number of fighters, ${ }^{52}$ and bombs are mainly used to create initial confusion, after which the rebels attack the security forces with guns. A second assumption that is implicit in the theoretical framework is the assumption that different Maoists groups operate independently. At first sight, this assumption could be too strong, as the main Maoist outlet (CPI Maoist) is in theory an integrated party movement that is led by a secretary general. However, the reality of guerilla warfare does not allow for significant organisational integration, as the CPI (Maoist) Central Committee highlights: "[t]he essential principle forming the basis of our Party structure is political centralisation combined with organisational decentralisation." ${ }^{3}$ Thus, the key military units operate at a lower level, in so-called the "Sub-Zonal, Zonal/District Commands". ${ }^{4}$ These units can independently stage attacks and they focus on geographic areas that broadly correspond to districts analysed in this paper. Moreover, these local command units are closely linked to the local party organisations that play an important role in gathering financial support for the Naxalites.

\subsection{Alternative explanations and robustness checks}

The main results are consistent with the model developed in section 2 and the anecdotal evidence presented in section 3 . This subsection addresses the extent to which alternative mechanisms can explain the observed patterns.

\subsubsection{Violent appropriation}

Tables 5 and 6 strongly suggest that the main results are driven by retaliation against civilian collaborators. However, these results could still be consistent with appropriation theories (Dal Bó and Dal Bó, 2011; Dube and Vargas, 2011) if the true motive of targeted killings is not accurately recorded in the SATP reports. A negative relationship between shocks and violence could be observed if Maoists increase their appropriation activities in response to bad

\footnotetext{
52 "75 Central Reserve Police Force personnel and a State Policeman were killed in an attack by about 1,000 CPI-Maoist cadres in Dantewada district." (SATP Timelines, Chattisgarh, 2010)

53 "Strategy and Tactics of the Indian Revolution", Central Committee (P) CPI (Maoist), February 2005. Accessed on www.satp.org.

54 "Resolutions of the 2nd Meeting of Central Regional Board", February 2005. Accessed on www.satp.org.
} 
shocks and if violence is proportional to appropriation. ${ }^{55}$ From a theoretical perspective, this interpretation would require the civilian population to have assets that do not depend too strongly on local economic conditions. However, these theories cannot explain why violence against the government and violence against civilians would react differently to income shocks in the absence of natural resources. Moreover, if the rebels strategically choose the extent to which they loot civilians (as in Azam, 2006), the presence of natural resources should mitigate the impact of negative productivity shocks on violence against civilians. I find no evidence of such a mitigation effect. While the Maoists clearly tax the local economy and they do this under the threat of violence, the violence that results from appropriation may have a different logic than the lethal violence that this paper investigates. The SATP timelines provide ample anecdotal evidence on the importance of lethal violence against informers. The Maoists communicate openly about civilian casualties and they typically refer to their victims as police informers (as shown in table 5). Even if the victims of violence did in fact refuse to pay levies to the Maoists, this open communication suggests that the intensity of violence against civilians could be driven by the rebels' goal to optimally deter (and punish) collaboration.

\subsubsection{Incapacitation and precision of attacks}

Berman et al. (2011a) find that higher unemployment inhibits insurgent attacks against security forces. ${ }^{56}$ These authors hypothesise that high unemployment makes civilians more willing to share information with counterinsurgency forces. They also argue that the resulting incapacitation effect might force rebels to switch towards less precise attacks that inflict more "collateral damage". In the context of India's Naxalite conflict, the incapacitation effect appears to be weak. The positive sign of the impact of rainfall shocks on security force casualties is not significant at conventional levels (and only positive in the absence of mineral resource wealth). The theoretical framework offers one explanation of why the incapacitation effect is limited: the rebels may effectively prevent collaboration by increasing violence against civilians. Furthermore, the theoretical framework and the empirical findings suggest that the incapacitation effect could be outweighed by the opportunity cost channel if the rebel group

\footnotetext{
${ }^{55}$ In the context of India, Sekhri and Storeygard (2010) rely on a similar argument to explain why atrocities against scheduled castes increase in low-rainfall years. Hence, it is possible that the observed increase in violence stems from the Maoists' goal to protect vulnerable populations against atrocities. This interpretation seems at odds with the fact that many victims of Maoist violence are in fact tribals. Miguel (2005) finds that extreme rainfall shocks lead to increased witch killings in Tanzania. While the author argues that income shocks are at the heart of the underlying mechanism, it is unclear whether these murders are driven by a desire to appropriate the possessions of witches.

${ }^{56} \mathrm{My}$ paper complements the findings of this closely related study in three ways. First, it overcomes reverse causality concerns by relying on an exogenous source of variation in labour income (i.e. rainfall). Second, it presents evidence on retaliatory violence which further underlines the crucial role of police informers. Third, my paper also sugggests how the conflicting findings in this strand of literature can be reconciled by taking the structure of the rebels' tax base into account.
} 
has access to external sources of funding.

In principle, the increase in civilian casualties that is observed in response to negative shocks could still be the result of a change in violence technology and decreased attack precision. However, such a collateral damage interpretation cannot explain the impact of rainfall on targeted civilian casualties (table 6). The results on untargeted civilian casualties suggest that indirect victims follow the pattern of attacks against the government. This suggests that if there is decreased precision, it is not the results of incapacitation (as argued by Berman et al., 2011a). While the elasticity on untargeted casualties is larger than the one on government casualties (which implies reduced precision), violence against the government goes up in response to negative productivity shocks in mineral rich areas. Incapacitation would predict that government casualties go down in response to negative income shocks. Columns (5) and (6) of table 6 further confirm that the observed effects on government casualties are not driven by attacks that also lead to civilian deaths.

\subsubsection{Police activism}

A third alternative explanation for the main results relies on the activities of the police forces. Mining districts might have greater police presence, which offers more opportunity for the rebels to respond to rainfall shocks with increased violence against police forces. Hence, negative rainfall shocks could lead to more violence against civilians in any district and to violence against the security forces in those districts with a large security force presence. This explanation seems unlikely to drive the results, as higher police activity in mining district would mainly lead to higher levels of violence against the security forces in any given year. In an extreme version of this argument, violence against the police should be zero in non-mining districts. However, mining districts only account for $40 \%$ of the districts that see any police casualties. Furthermore, the proportionality of the impact of rainfall shocks to the average levels of violence against the police is already accounted for by the multiplicative fixed effects in the Poisson model. This argument can also help to address concerns that Maoist violence against the police is purely driven by the aspiration to control mineral resources. ${ }^{57}$ Again, one would expect this channel to operate through higher levels of violence, which are accounted for by the fixed effects. Nevertheless, it remains possible that mining regions face types of police activity which are not captured by average levels of violence against the police but do shape the incentives for rebels to attack the security forces in response to a productivity shock. Column (7) in table 7 presents one way to account for the possibility that mining regions would be more prone to police activism. I measure the salience of police activity by

\footnotetext{
${ }^{57}$ Similarly, it is unclear whether higher extortion would increase police activity in mining regions, especially because the Maoists are suspected of having cozy ties with the industrialists they tax. "You will not find any businessman who has been attacked,' says Ajit Doval, a former head of India's Intelligence Bureau, "only poor tribals and policemen." (The Economist, 25 February 2005, http://www.economist.com/node/15580130).
} 
the number of incidents in which the Maoists suffered casualties in the baseline year (2005). If my results are driven by the differential impact of rainfall in districts with higher police activity, the coefficient on the interaction term of rainfall and baseline maoist casualties could pick up the differential effect of mineral resource wealth. However, the coefficient on the interaction term is estimated to be very small, while the coefficient on the interaction term with mineral wealth retains its magnitude and significance.

\subsubsection{Mining activity}

The current analysis cannot provide direct evidence on taxation by rebel groups, which is the key mechanism within my framework that explains the differential impact of rainfall shocks in mining regions. The Maoists publicly campaign against mining activity on the grounds that mines lead to pollution and the displacement of the tribal population (Kujur, 2009). Rebel groups in mining regions are thought to bank on the wide-spread resentment against mining activity. The first order effect of grievances against mines should operate through average levels of violence, which are accounted for by the fixed effects. However, the adverse impact of mining activity on rural communities could inspire certain alternative explanations of the observed differential impact of rainfall in mining regions. In particular, rebel groups could be more effective in recruiting from mining regions because of two reasons. First, it may be that a given rainfall shock has a larger impact on agricultural productivity of potential recruits as a result of environmental degradation or displacement. This channel could even be strengthened through political economy factors. If districts that produce minerals have weaker political institutions, this could exacerbate the impact of a given rainfall shock (as suggested in the ordered conflict model of Besley and Persson, 2010). While the analysis cannot fully rule out this possibility, the estimated rice production function in tables 3 and 4 failed to pick up any differential effect of rain on agricultural output in mining regions. Furthermore, a political resource curse interpretation is undermined by the fact that key policies are set at the state level and all selected states (with the exception of Bihar) produce key minerals. ${ }^{58}$ A second channel that relies on the environmental impact of mining activity is the possibility that grievances against mines create an additional incentive for individuals to join the Maoists. While these channels are different from the pure budget constraint mechanism as presented in the theory, the main difference could be one of interpretation. First, if the impact of rainfall shocks is more severe in mining regions, this could affect the communities who are considered for recruitment (for instance, the tribal population) more than the tax base of the rebel group. Hence, this channel could formally be equivalent to the mechanism proposed earlier. Similarly, the grievance against mines could create an additional pull factor which makes the rebel group's budget constraint less dependent on local economic conditions. In

\footnotetext{
${ }^{58}$ The results are robust to the inclusion of state-specific effects of rainfall and year effects instead of state-year fixed effects. State specific effects of rainfall could capture state-specific political institutions.
} 
this sense, the grievance mechanism could be understood within my theoretical framework.

It is possible to test the importance of the tribal population explicitly. If the conflict between mines and rural communities mainly affects tribal groups (as suggested by Kujur, 2009), one could expect the grievance effect of mines to be stronger in tribal areas. To test this hypothesis, I include a triple interaction of mineral wealth, the share of the tribal population, and rainfall in the baseline model. The coefficient on the triple interaction term should be negative and significant (for security force casualties), if the effect of rainfall shocks in mining districts is larger for tribal districts. This should be the case if the impact of mining mainly operates through the grievances of the tribal population. However, the coefficient on the triple interaction is insignificant (table 7, columns 1 and 4, for civilian and security force casualties respectively).

\subsubsection{Accounting for floods and alternative rainfall measures}

While rainfall was found to be positively related to rice production, the impact of rain on agricultural output is theoretically ambiguous: higher rainfall could boost productivity but it could also spur floods and cause crop damage. ${ }^{59}$ One concern is that my analysis captures the incapacitation effect of floods. Floods could destroy output and capital used by rebel groups, which subsequently leads to a decrease in violence. Yet, this interpretation cannot fully account for the observed heterogeneity in impacts between mining and non-mining regions. In an attempt to further confirm that my findings result from the impact of rainfall shocks on the opportunity cost of conflict (rather than the destruction of conflict capital), I allow for the impact of rainfall to be different in flood-prone areas (table 7, columns 2 and 5). ${ }^{60}$ The results confirm that these districts are not driving the results. Strikingly, the negative impact on violence against civilians is mitigated in these districts, which is consistent with the idea that positive rainfall shocks in flood prone areas do not necessarily result in an increase in the opportunity cost of engaging in conflict. Therefore, it seems unlikely that the main results are driven by the impact of floods.

As an additional robustness check, I define dry district-years as observations that see Kharif season rainfall below $20 \%$ of the district average between 2004 and $2010 .{ }^{61}$ Using this dry year dummy as the relevant rainfall shock yields results that are close to those obtained earlier.

\footnotetext{
${ }^{59}$ In my dataset, I find no convincing evidence of a negative impact of excess rainfall on agricultural output. However, the logarithmic specification already accounts for the decreasing returns to rainfall levels, which are clearly present.

${ }^{60}$ As defined by the Indian Vulnerability Atlas (2006).

${ }^{61} 22 \%$ of all district-years are categorised as "dry years" according to this definition.
} 


\subsubsection{Alternative mineral definitions}

The mineral variable employed in the main analysis was constructed using various sources. To assess if any bias was induced by using 2005-2006 production data for bauxite and iron, table 7 (columns 3 and 6) presents the key results for an alternative measure of district-level production of bauxite and iron mining, which was published by the US Geological Survey. ${ }^{62}$ This survey does not provide district-level information on coal mining. Therefore, a dummy for coal mining activity (which is based on 2003 data and does not suffer from severe endogeneity concerns) is added in a separate interaction term. The key results go through in this alternative specification. While the coefficient on coal fails to gain significance if it is separately estimated, it is still negative and large. The coefficient on bauxite and iron remains negative and significant.

\section{Conclusion}

Focusing on India's Naxalite conflict, this paper investigated the logic of targeted violence against civilians versus security forces. In line with the asymmetric nature of the Naxalite conflict, I hypothesised that income shocks should have different impacts on violence depending on the resource environment. In the absence of external sources of revenue, the Naxalites may not be able to exploit a negative labour income shock to boost recruitment. However, the centrally funded government forces are not bound by this constraint. Therefore, collaboration between the government and the civilian population becomes more attractive in response to a negative labour income shock, which is expected to spark violence against civilians by the Naxalites in an attempt to deter collaboration. The Naxalites can only exploit negative labour income shocks to increase attacks against the government if they have access to external sources of funding. My empirical analysis supported these hypotheses. Exploiting exogenous variation in rainfall in a panel of annual casualty numbers, negative rainfall shocks were found to increase Maoist violence against civilians. Importantly, this result was found to be driven by violence against civilian collaborators. Negative shocks were only associated with increased violence against the security forces in those districts that produce key minerals.

The results of this paper shed new light on the conflicting results in the literature that links labour income shocks to violence. In particular, the analysis suggests that the combination of the relative financial capacity of the parties involved in the conflict and the structures of the underlying tax bases could play an important role in determining the sign of the relationship between labour income shocks and conflict.

The findings of this paper have important implications for the design of conflict resolution policies and counter-insurgency strategies. A first set of policies could aim to mitigate negative

\footnotetext{
${ }^{62}$ U.S. Geological Survey, 2007, "2005 Minerals Yearbook India", p.13.
} 
income shocks, in an attempt to block rebel recruitment through the opportunity cost channel. Such policies could include targeted employment programmes, investments in agriculture, and subsidised rainfall insurance. However, this paper suggests that these policies may only be effective at restraining rebel's fighting capacity against the government in mineral-rich areas. In mineral-poor areas, the structure of the rebels' tax base already prevents the rebels from benefiting from negative income shocks in the absence of mitigation policies. If the policy goal is to prevent targeted attacks on civilians, mitigation policies could be effective regardless of the resource environment. However, a potential drawback of mitigation policies is that they could make it harder for the security forces to recruit informers. In line with the latter idea, a second set of counter-insurgency policies could in fact exploit negative income shocks to attract civilian collaboration with the government. By offering rewards or services that are conditional on collaboration, the government could benefit from negative income shocks to gather more information and to undermine the rebels' fighting capacity (as suggested by Berman et al., 2011a). This paper qualifies the latter policy prescription in two ways. First, a collaboration strategy may be less effective in mineral-rich areas, where negative income shocks could benefit both the government (through increased collaboration) and the insurgents (through increased rebel recruitment). Second, this paper points at an important danger of collaboration strategies. My findings suggest that the rebels may use targeted violence against civilians to match the increased appeal from collaboration due to negative income shocks. In India's Naxalite conflict, various government agencies already encourage civilian collaboration through a variety of policies, including monetary rewards for information, conditional services, and recruitment into vigilante groups. However, the observed retaliatory violence reflects the fact that the civilian population is not sufficiently protected against increased reprisals. It could also be that the rewards from collaboration in the Naxalite conflict are too limited to outweigh the risk of retaliation by the Naxalites. In such an environment, a real danger of policies that aim to attract civilian collaboration is that they mainly increase the vulnerability of the population to attacks by insurgents. The logic of such targeted violence against civilians deserves more attention from both policy makers and researchers, in India's Naxalite conflict and beyond. 


\section{References}

[1] Azam, Jean-Paul. 2002. "Looting and Conflict between Ethnoregional Groups: Lessons for State Formation in Africa". Journal of Conflict Resolution, 46(1): 131-53.

[2] Azam, Jean-Paul and Anke Hoeffler. 2002. "Violence against Civilians in Civil Wars: Looting or Terror?", Journal of Peace Research, 39(4): 461-485.

[3] Azam, Jean-Paul. 2006. "On Thugs and Heroes: Why Warlords Victimize Their Own Civilians." Economics of Governance, 7(1): 53-73.

[4] Balcells, Laia. 2010. "Rivarlry and Revenge: Violence againsts Civilians in Conventional Civil Wars", International Studies Quarterly.

[5] Banerjee, Abhijit and Lakshmi Iyer. 2010. "History, institutions and economic performance: the legacy of colonial land tenure systems in india", American Economic Review, 95(4): 1190-1213.

[6] Berman, Eli, Michael Callen, Joseph Felter and Jacob N. Shapiro. 2011a. "Do working men rebel? Insurgency and unemployment in Afghanistan, Iraq and the Phillipines", Journal of Conflict Resolution, forthcoming.

[7] Berman, Eli, Joseph Felter and Jacob N. Shapiro. 2011b. "Can Hearts and Minds Be Bought? The Economics of Counterinsurgency in Iraq", Journal of Political Economy, forthcoming.

[8] Besley, Timothy and Torsten Persson. 2010. "The Logic of Political Violence", Quarterly Journal of Economics, forthcoming.

[9] Bholken, Anjali, Thomas Sergenti and Ernest John, 2010. "Economic Growth and Ethnic Violence: An Empirical Investigation of Hindu-Misulim Riots in India", Journal of Peace Research, 47(5): 589-600.

[10] Blattman, Christopher and Edward Miguel. 2010. "Civil War", Journal of Economic Literature, 48(1): 3-57.

[11] Bueno de Mesquita, Ethan. 2011. "Rebel Tactics", Mimeo, University of Chicago.

[12] Burgess, Robin, Matthew Hansen, Benjamin Olken, Peter Potapov and Stefanie Sieber. 2011. "The Political Economy of Deforestation in the Tropics", mimeo, LSE.

[13] Burgess, Robin, Olivier Deschenes, Dave Donaldson and Michael Greenstone. 2011. "Weather and Death in India", mimeo, LSE. 
[14] Borooah, V. K. 2008. "Deprivation, Violence and Conflict": an analysis of Naxlite Activity in the Districts of India", Internactional Journal of Conflict and Violence, 2(2): 317-333.

[15] Chassang, Sylvain and Gerard Padro i Miquel. 2009. "Economic Schocks and Civil War", Quarterly Journal of Political Science, 4(3): 211-228.

[16] Ciccone, Antonio. 2008. "Transitory Economic Shocks and Civil Conflict", Mimeo, Pompeu Fabre.

[17] Cole, Shawn, Andrew Healy and Eric Werker. 2011. "Do Voters Demand Responsive Governments? Evidence from Indian Disaster Relief", Journal of Development Economics, Forthcoming.

[18] Collier, Paul and Anke Hoeffler. 2007. "Civil War" in Handbook of Defense Economics, K. Hartley and T. Sandler, Elsevier, Holland.

[19] Dal Bó, Ernesto and Pedro Dal Bó. 2004. "Workers, Warriors, and Criminals: Social Conflict in General Equilibrium." Journal of the European Economic Association, forthcoming.

[20] Do, Quy-Toan an Lakshmi Iyer. 2010. "Poverty, social divisions and conflict in Nepal: an empirical analysis.", Journal of Peace Research, forthcoming.

[21] Dube, Oeindrilla and Juan F. Vargas. 2011. "Commodity Price Shocks and Civil Conflict: Evidence from Colombia." Review of Economic Studies, forthcoming.

[22] Eck, Kristine and Lisa Hultman. 2007. "One Sided Violence against Civilians in War: insights from New Fatality Data", Journal of Peace Research, 44.

[23] Fearon, James. 2005. "Primary Commodities Exports and Civil War", Journal of Conflict Resolution, 49(4).

[24] Hausman, J.A., Hall, H., and Griliches, Z. 1984. "Econometric Models for Count Data with An Application to the Patents-R\&D relationship”, Econometrica, 52(4): 909-938.

[25] Humphreys, Macarthan and Jeremy M. Weinstein. 2006. "Handling and Manhandling Civilians in Civil War", American Political Science Review, 100(3).

[26] Iyengar, Radha, Jonathan Monten, and Hanson Matthew. 2011. "The Impact of Aid on the Labor Market for Insurgents", NBER Working Paper, No.17297.

[27] Janus, Thorsten. 2011. "Natural resource extraction and civil conflict." Journal of Development Economics, forthcoming. 
[28] Joshi, P. K., P. S. Birthal, and V. A. Bourai. 2002. "Socioeconomic Constraints and Opportunities in Rainfed Rabi Cropping in Rice Fallow Areas of India", Mimeo, National Centre for Agricultural Economics and Policy Research, New Delhi.

[29] Kalyvas, Stathis N. 2006. The Logic of Violence in Civil War. Cambridge and New York: Cambridge University Press.

[30] Kujur, Rajat. 2008. "Naxal Movement in India: a Profile", IPCS Research Papers, New Delhi.

[31] Kujur, Rajat. 2009. "Naxal Movement in 2008: an Assessment", IPCS Issue Brief, New Delhi.

[32] Macours, Karen. 2010. "Increasing Inequality and Conflict in Nepal", Oxford Economic Papers, 63(1): 1-26.

[33] Miguel, Edward, Shanker Satyanath, and Ernest Sergenti. 2004. "Economic Shocks and Civil Conflict: and Instrumental Variables Approach." Journal of Political Economy, 112(4): 726-53.

[34] Miguel, Edward. 2005. "Poverty and Witch Killing", Review of Economic Studies, 72(4).

[35] Murshed S. Mansoob, and Scott Gates. 2005. "Spatial horizontal inequality and the Maoist insurgency in Nepal. Review of Development Economics, 9: 121-34 .

[36] Nilakantan, Rahul and Saurabh Singhal. 2011. "The Economic Costs of Naxalite Violence and the Economic Benefits of a Unique Robust Security Response", Mimeo USC.

[37] PACS. 2009. "Drought in India: Challenges and Initiatives", PACS Programme, New Delhi.

[38] Prasad, Chandra Shekhar. 2006. "Sixty Years of Indian Agriculture: 1947 to 2007", New Century Publications, New Delhi.

[39] Restreppo, Jorge and Michael Spagat, "Civilian Casualties in the Columbian Conflict: A New Approach to Human Security", Mimeo CEPR.

[40] Ross, Michael. 2004. "What do we know about the Relationship between Natural Resources and Civil War", Journal of Peace Research, 41(3).

[41] Sekhri, Sheetal and Adam Storeygard, 2010. "The Impact of Climate Variability on Vulnerable Populations: Evidence on Crimes against Women and Disadvantaged Minorities in India", mimeo, University of Virginia and Brown University. 
[42] Srivastava, Devyani. 2009. "Terrorism \& Armed Violence in India". IPCS Special Report (Institute of Peace and Conflict Studies), 71.

[43] Weinstein, Jeremy M. 2005. "Resources and the Information Problem in Rebel Recruitment", Journal of Conflict Resolution, 49.

[44] Weinstein, Jeremy M. 2007. Inside Rebellion - The Politics of Insurgency Violence, Cambridge University Press, Cambridge, UK.

[45] Wooldrige, J. M. 2002. Econometric Analysis of Cross Section and Panel Data, Cambridge (MA), MIT Press. 


\section{Appendix}

\section{A.1. Theoretical Framework}

\section{A.1.1. Proof of Proposition 1 and 2}

From expression 6 , it can easily be derived that:

$$
\frac{\partial\left(\tau^{*} F\right)}{\partial \theta}=-\frac{C_{2}}{C_{1}}[(1-p)]
$$

The relationship between the total number of fighters and labour productivity is given by:

$$
\frac{\partial F}{\partial \theta}=-p \frac{R}{\theta^{2}} \leqslant 0
$$

If $R=0$, it follows that:

$$
\begin{gathered}
\frac{\partial\left(\tau^{*} F\right)}{\partial \theta}=-\frac{C_{2}}{C_{1}}[(1-p)]<0 \\
\frac{\partial\left(1-\tau^{*}\right) F}{\partial \theta}=\frac{C_{2}}{C_{1}}[(1-p)]>0
\end{gathered}
$$

If $R>0$,it can be seen that:

$$
\frac{\partial\left(\tau^{*} F\right)}{\partial \theta}=-\frac{C_{2}}{C_{1}}(1-p)
$$

This effect does not depend on $R$. While changes in $R$ change both $\tau^{*}$ and $F,\left(\tau^{*} F\right)$ remains constant as the indifference condition does not depend on $R$. However, the impact on the number of fighters employed against the government depends on $R$ :

$$
\frac{\partial\left(1-\tau^{*}\right) F}{\partial \theta}=-p \frac{R}{\theta^{2}}+\frac{C_{2}}{C_{1}}(1-p)
$$

Clearly, we can find an $\bar{R}$ such that:

$$
p \frac{\bar{R}}{\theta^{2}}=\frac{C_{2}}{C_{1}}(1-p)
$$




$$
\frac{\partial\left(1-\tau^{*}\right) F}{\partial \theta}<0 \Leftrightarrow R>\bar{R}
$$

The comparative statics results described above require interior solutions. In particular, $L$ needs to be sufficiently large to rule out a corner solution in which the entire population has joined the rebel group (and the derivative of interest is not defined). In paricular, let $\tilde{L}=p \widetilde{L}+p \frac{\bar{R}}{\theta}$. If $L>\tilde{L}$, we know that $F(\bar{R})<L$. Similarly, the comparitive statics may not be defined if $\tau=1$. This corner solution can be ruled out by choosing $X$ sufficiently small..

\section{A.1.2. A Microfoundation of Violence against Civilians}

In this section, I present an extension of the baseline model that links violence against civilians more explicitly to the retaliation capacity of the rebel group. It is assumed a fraction $\alpha_{1}+\alpha_{2}$ of the population receives valuable information. Implicitly, the model in the main body already incorporated this assumption. Fraction $\alpha_{1}$ of the population is non-strategic and always provides information to the government. Fraction $\alpha_{2}$ receives valuable information and chooses to pass on this information depending on the costs and benefits. A fraction $1-\alpha_{1}-\alpha_{2}$ does not receive information. These informer types are hidden. It is assumed the government pays $X$ for valuable information that is provided by the "opportunistic informants" $\alpha_{2}$. The collaboration of the $\alpha_{2}$ population is assumed to be critical. The rebel group will lose its fighting capacity if and only if the $\alpha_{2}$ population passes on information to the government.

In contrast to the earlier model, the population does not directly observe $\tau F$. Instead, it observes the number of non-security force killings by the rebel group among the $\alpha_{1}$ informers, which is a monotonically increasing function of $\tau F, K(\phi \tau F)$, with $0 \leqslant \phi \leqslant 1$. For $\phi=1$, $K(\phi \tau F)$ perfectly reveals the minimum investment in retaliation capacity. This extension microfounds the targeting of civilians. In particular, the rebel group now kills non-strategic informers to show that they have fighters devoted to retaliation activities. The ability to target $\alpha_{1}$ informers also reflects monitoring capacity. Without investments in monitoring capacity, the rebel group may be able to kill civilians, but it will fail to target only informers. It is assumed that the types are revealed after the killing, so that the population can derive both 
the strength of the rebels devoted to controlling civilians and their monitoring capacity. ${ }^{63}$

The timing of the altered game is as follows:

1. Nature draws:

- The informant types in the population, with probabilities $\alpha_{1}$ for unconditional informers, $\alpha_{2}$ for opportunistic informers, and $1-\alpha_{1}-\alpha_{2}$ for the remaining population.

2. Production, rebel recruitment, and appropriation take place according to equation 1.

3. $\alpha_{1}$ informers provide information to the government.

4. The rebel group chooses $\tau F$ and $\phi$.

5. The $\alpha_{2}$ population:

- Observes the number of killings of $\alpha_{1}$ informers: $k=K(\phi \tau F)$

- Decides to provide information $i \in(0,1)$.

6. The pay-offs are realised:

- The rebel group's pay-off: $W(\tau)=\left(1-i^{*}\right)(1-\tau) F$

- The pay-off of the $\alpha_{2}$ population is given by: $(1-p) \theta+i(X-C(\tau F, \theta(1-p)))$

This game is essentially a simultaneous game that is preceded by a stage in which the rebel group shows its minimum retaliation capacity $\phi \tau F$. The subgame perfect equilibrium will specify optimal strategies in the simultaneous game and the optimal revelation of minimum capacity, $\phi \tau F$, in the first stage.

Proposition A.1: In the Subgame Perfect Equilibrium, the rebel group sets $\tau^{*} F$ so that equation 6 holds with equality. It sets $\phi^{*}=1$, killing $K\left(\tau^{*} F\right)$ civilians. The informants choose $i^{*}=1$ if $k<K\left(\tau^{*} F\right)$ and $i^{*}=0$ if $k \geqslant K\left(\tau^{*} F\right)$.

Proof The existence of the equilibrium is a corollary of proposition 1 . Consider a strategy in which $i=0$ for at least one $\widetilde{k}$ such that $\widetilde{k}<K\left(\tau^{*} F\right)$. It is clear that the rebel group will optimally set $\widetilde{\tau}<\tau^{*}$ in response to this strategy. It will make sure that $\widetilde{k}=K(\widetilde{\tau} F)$. However, for $\tau<\tau^{*}$, the optimal strategy for the population is to set $i=1$. A strategy whereby $i=0$ for $\widetilde{k}=K\left(\tau^{*} F\right)$ cannot be optimal, as the technology of killings is such that $\widetilde{k}$ can only be achieved for $\tau \geqslant \tau^{*}$. Given that $\tau \geqslant \tau^{*}$, it is optimal to choose $i=1$.

\footnotetext{
${ }^{63}$ It seems reasonable to assume that investments in retaliation capacity coincides with an investments in $(1-\tau) F$. Therefore, in principle, the rebel group could show its retaliation capacity based on $(1-\tau) F$. Nevertheless, an increasing function $H(\varphi(1-\tau) F)$ ), which could correspond to attacks against the government, would not work. While high retaliation capacity could imply a low value of $H$, an arbitrarily low $H$ can also be achieved at no cost by just reducing $\varphi$.
} 
The comparative statics are identical to the results in section 2 . 


\section{A.2. Maps}

Figure 1: Districts Included in Data Set

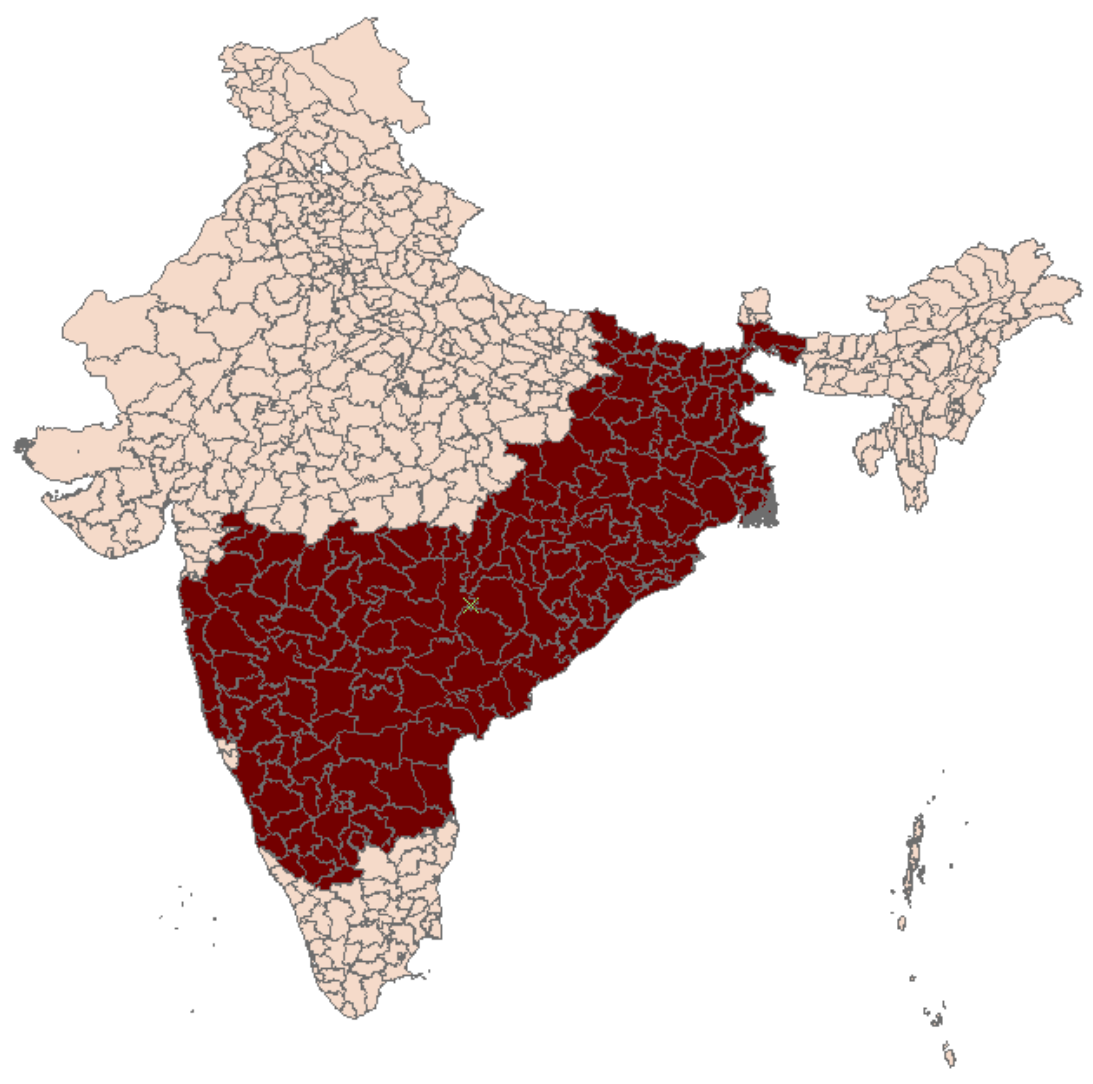


Figure 2: Affected Districts

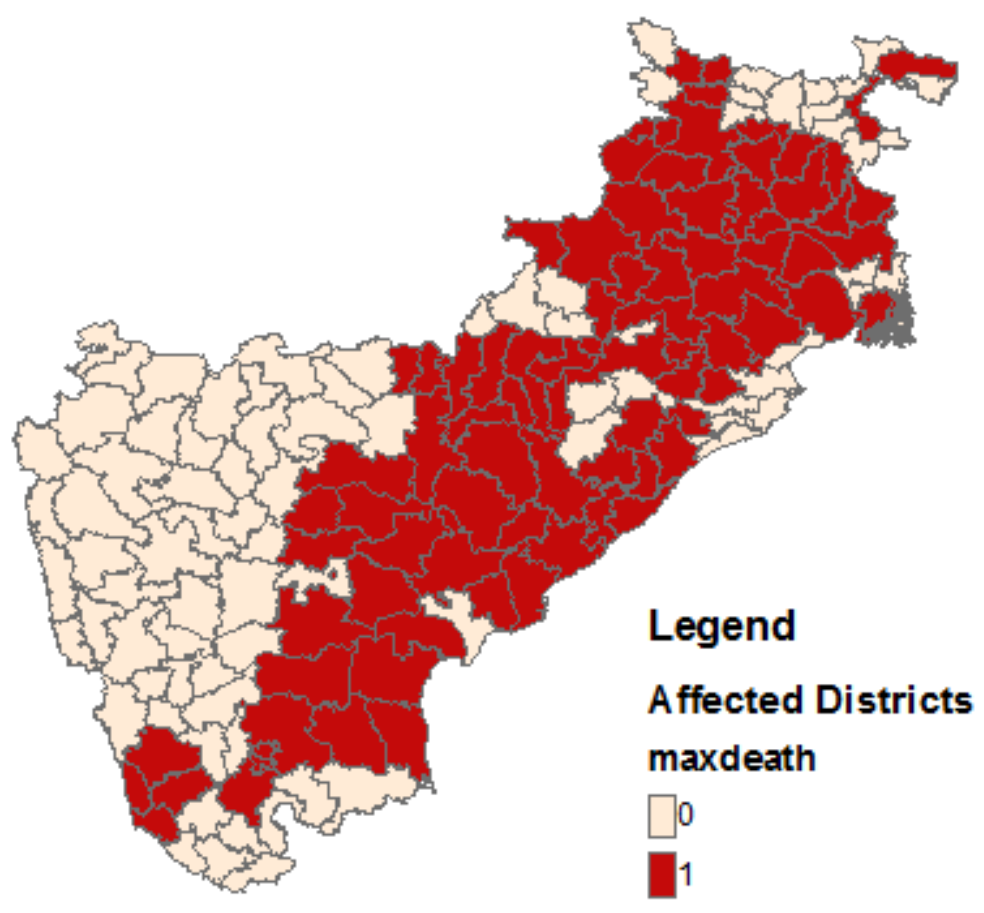

Notes: Affected districts see at least one casualty of any type between 2005 and 2010 . 


\section{Figure 3: Civilian casualties}

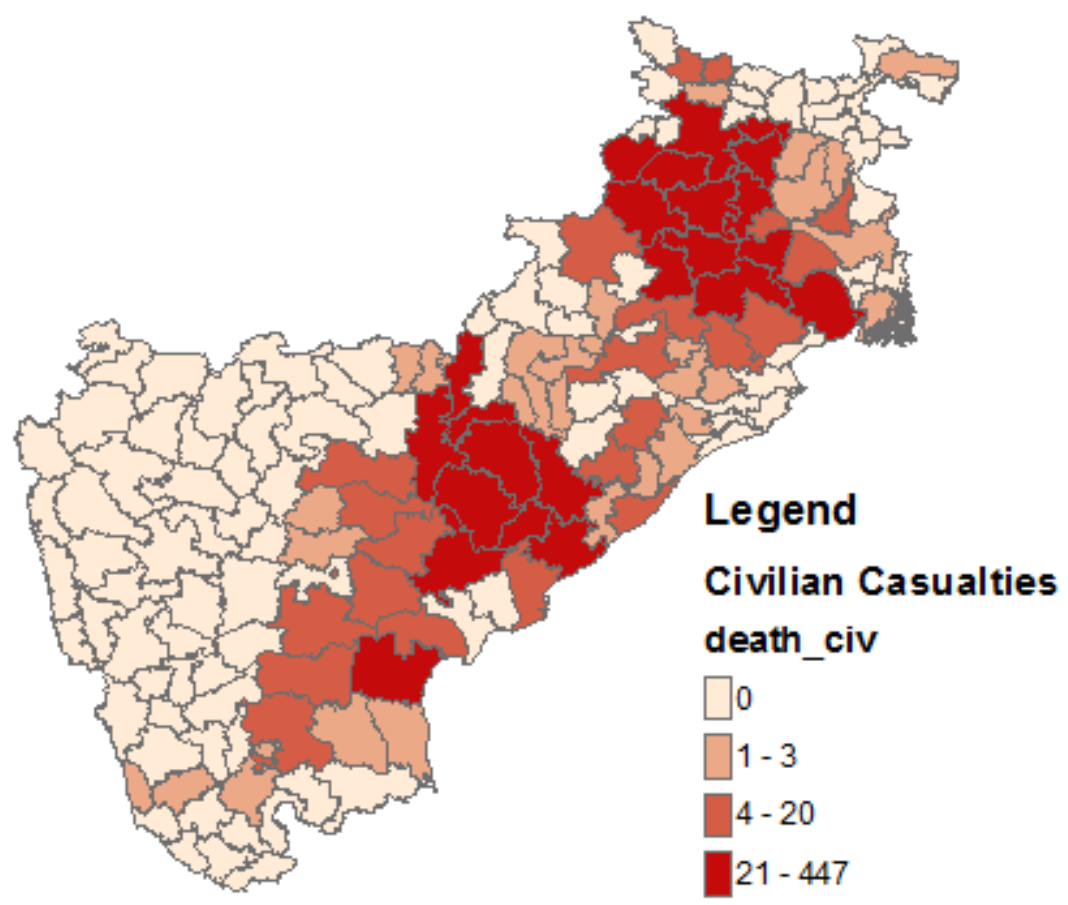

Notes: Total number of civilian casualties (per merged district) between 2005 and 2010 . 
Figure 4: Security Forces Casualties

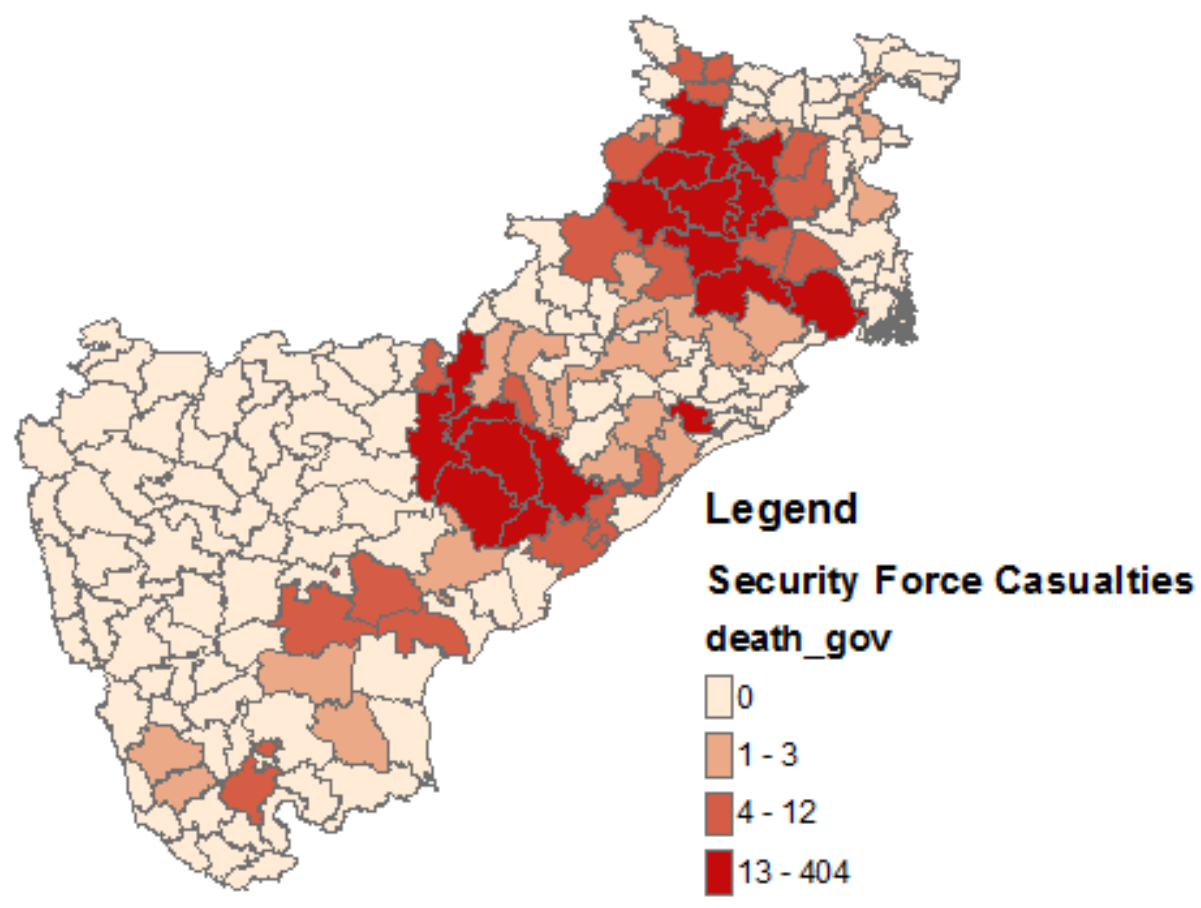

Notes: Total number of security force casualties (per merged district) between 2005 and 2010 . 
Figure 5: Mineral Production

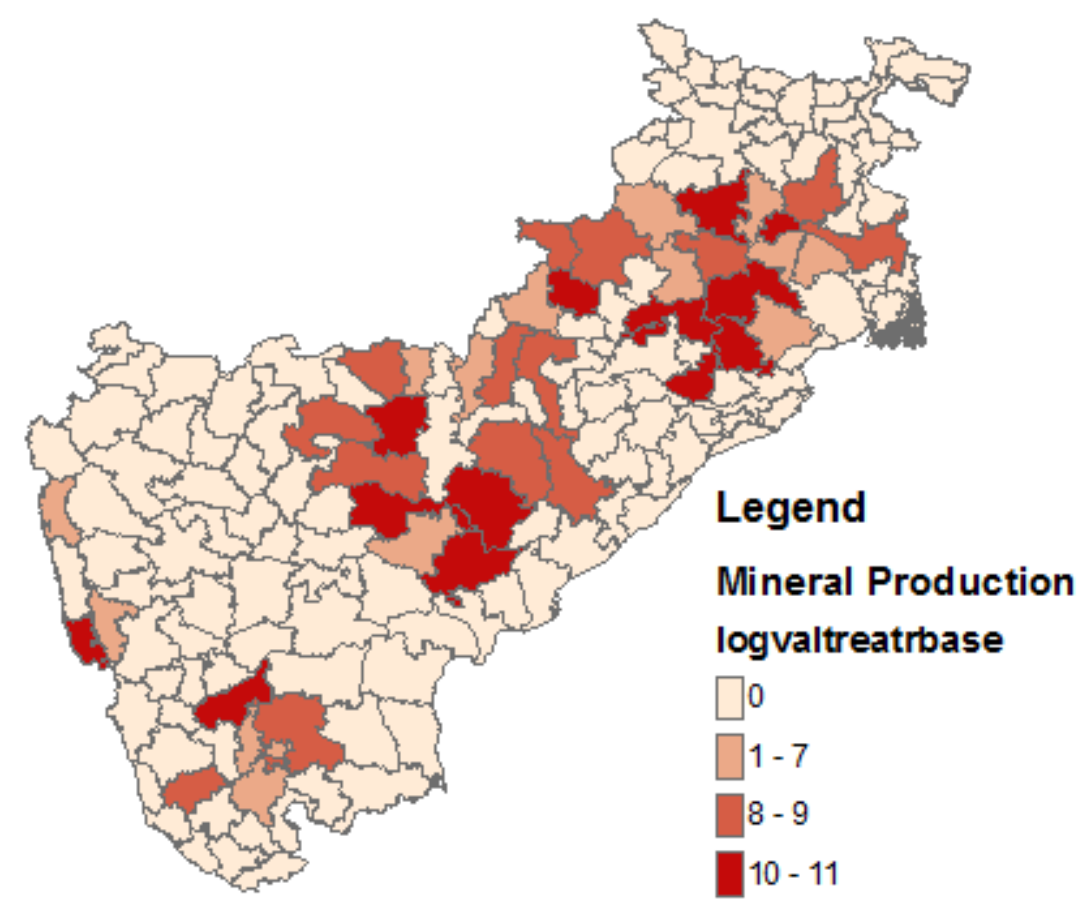

Notes: Logarithm of mineral production value (plus 1), measured at baseline as described in the text. 


\section{A.3. Tables}

Table 1: Summary Statistics

Panel A (district-year level)

\begin{tabular}{|c|c|c|}
\hline & Mean & Observations \\
\hline Civilian casualties & $\begin{array}{c}1.91 \\
(12.3)\end{array}$ & 1002 \\
\hline Maoist casualties & $\begin{array}{c}1.61 \\
(7.66)\end{array}$ & 1002 \\
\hline Security forces casualties & $\begin{array}{c}1.29 \\
(7.16)\end{array}$ & 1002 \\
\hline Kharif season rainfall (mm) & $\begin{array}{l}1053 \\
(639)\end{array}$ & 1169 \\
\hline Kharif season rainfall (mm, logarithmic) & $\begin{array}{c}6.81 \\
(0.54)\end{array}$ & 1169 \\
\hline Rice production (tonnes) & $\begin{array}{c}248,117 \\
(283,351)\end{array}$ & 285 \\
\hline \multicolumn{3}{|l|}{ Panel B (district level) } \\
\hline Mineral wealth dummy & $\begin{array}{c}0.25 \\
(0.44)\end{array}$ & 167 \\
\hline $\begin{array}{l}\log (\text { Mineral value }+1) \\
\text { (conditional on positive production value) }\end{array}$ & $\begin{array}{c}7.55 \\
(2.31)\end{array}$ & 42 \\
\hline Population density (pop $/ \mathrm{km}^{2}$ ) & $\begin{array}{c}419 \\
(381)\end{array}$ & 167 \\
\hline Scheduled tribe population (fraction of population) & $\begin{array}{c}0.14 \\
(0.17)\end{array}$ & 167 \\
\hline Forest area (fraction of district area) & $\begin{array}{c}0.20 \\
(0.19)\end{array}$ & 164 \\
\hline Scheduled caste population (fraction of population) & $\begin{array}{c}0.15 \\
(0.07)\end{array}$ & 167 \\
\hline Literate population (percentage) & $\begin{array}{c}62 \\
(13)\end{array}$ & 167 \\
\hline Flood prone dummy & $\begin{array}{c}0.32 \\
(0.47)\end{array}$ & 167 \\
\hline
\end{tabular}

Notes: See text for a detailed data description. Table A includes observations for 167 (merged) districts between 2005 and 2010. Rainfall data are from the Indian Meteorological Institute. Violence data are from the South Asia Terrorism Portal. Table B includes mineral data are for bauxite, iron and coal. Physical output data are based on various government publications between 2003 and 2005-2006, as described in the text. Output is evaluated at 2004-2005 prices. Forest cover data are from Government publications. Population data are from the 2001 census. 
Table 2: Rainfall shocks and Violence

\begin{tabular}{|c|c|c|c|c|}
\hline & $\begin{array}{c}\log (\text { production) } \\
\text { (1) }\end{array}$ & $\begin{array}{c}\text { Civilian } \\
\text { Casualties } \\
(2)\end{array}$ & $\begin{array}{c}\text { Security Forces } \\
\text { Casualties } \\
(3)\end{array}$ & $\begin{array}{c}\text { Maoist } \\
\text { Casualties } \\
(4)\end{array}$ \\
\hline $\log \left(\operatorname{rainfall}_{t}\right)$ & $\begin{array}{c}0.45^{* * *} \\
(0.14)\end{array}$ & $\begin{array}{l}-0.17 \\
(0.39)\end{array}$ & $\begin{array}{l}-0.29 \\
(0.60)\end{array}$ & $\begin{array}{l}-0.11 \\
(0.52)\end{array}$ \\
\hline $\log \left(\operatorname{rainfall}_{t-1}\right)$ & & $\begin{array}{c}-0.87^{* * *} \\
(0.28)\end{array}$ & $\begin{array}{c}-1.15^{* *} \\
(0.52)\end{array}$ & $\begin{array}{c}0.22 \\
(0.47)\end{array}$ \\
\hline Observations & 268 & 444 & 348 & 360 \\
\hline Districts & 123 & 74 & 58 & 60 \\
\hline Estimation & OLS & Poisson & Poisson & Poisson \\
\hline \multicolumn{5}{|c|}{$\begin{array}{l}\text { Notes: District-year level observations, covering } 2005-2010 \text { (2004-2006 in column } 1) \text {. Districts are merged } \\
\text { as described in the text. All regressions include district fixed effects, state-year fixed effects and mineral } \\
\text { dummy-year fixed effects. Standard errors are clustered at the district level. }{ }^{* * *} \mathrm{p}<0.01,{ }^{* *} \mathrm{p}<0.05, * \\
\mathrm{p}<0.1 \text {. }\end{array}$} \\
\hline
\end{tabular}




\section{Table 3: Baseline Results}

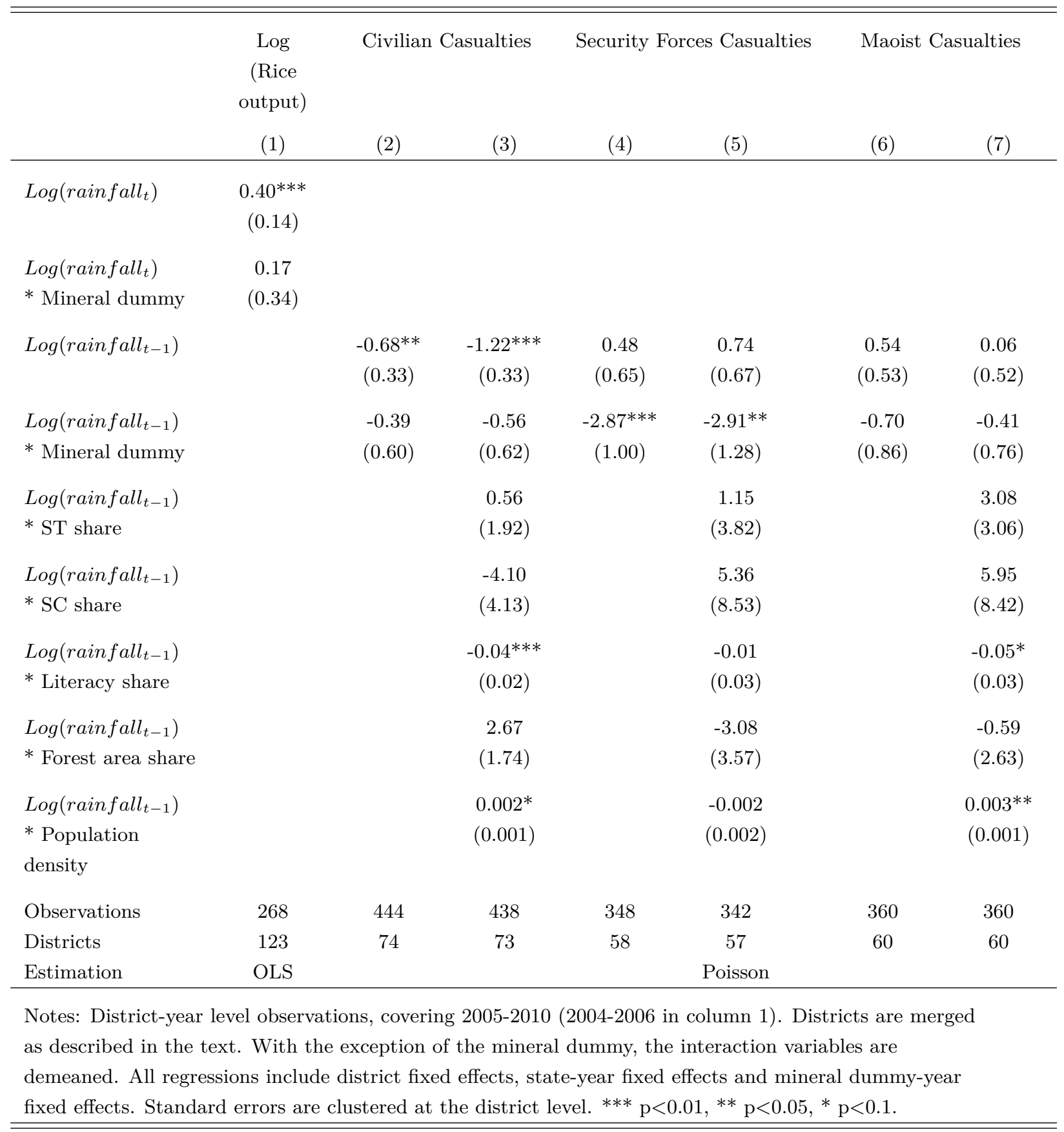


Table 4: Baseline Results (continuous mineral measure)

\begin{tabular}{|c|c|c|c|c|c|c|c|}
\hline & \multirow{2}{*}{$\begin{array}{c}\text { Log } \\
\text { (Rice } \\
\text { output) } \\
(1)\end{array}$} & \multicolumn{2}{|c|}{ Civilian Casualties } & \multicolumn{2}{|c|}{ Security Forces Casualties } & \multicolumn{2}{|c|}{ Maoist Casualties } \\
\hline & & $(2)$ & (3) & $(4)$ & $(5)$ & $(6)$ & $(7)$ \\
\hline $\log \left(\operatorname{rainfall}_{t}\right)$ & $\begin{array}{c}0.41^{* * *} \\
(0.14)\end{array}$ & & & & & & \\
\hline $\begin{array}{l}\log \left(\text { rainfall }_{t}\right) \\
* \log (\text { Mineral } \\
\text { value })\end{array}$ & $\begin{array}{c}0.016 \\
(0.048)\end{array}$ & & & & & & \\
\hline $\log \left(\right.$ rainfall $\left._{t-1}\right)$ & & $\begin{array}{c}-0.85^{* *} \\
(0.36)\end{array}$ & $\begin{array}{c}-1.25^{* * *} \\
(0.32)\end{array}$ & $\begin{array}{c}0.25 \\
(0.64)\end{array}$ & $\begin{array}{c}0.24 \\
(0.68)\end{array}$ & $\begin{array}{c}0.71 \\
(0.51)\end{array}$ & $\begin{array}{c}0.29 \\
(0.51)\end{array}$ \\
\hline $\begin{array}{l}\log \left(\text { rainfall }_{t-1}\right) \\
* \log (\text { Mineral } \\
\text { value })\end{array}$ & & $\begin{array}{c}0.00 \\
(0.06)\end{array}$ & $\begin{array}{l}-0.07 \\
(0.06)\end{array}$ & $\begin{array}{c}-0.29 * * * \\
(0.10)\end{array}$ & $\begin{array}{c}-0.29^{* *} \\
(0.14)\end{array}$ & $\begin{array}{l}-0.13 \\
(0.10)\end{array}$ & $\begin{array}{l}-0.11 \\
(0.09)\end{array}$ \\
\hline $\begin{array}{l}\log \left(\text { rainfall }_{t-1}\right) \\
* \text { ST share }\end{array}$ & & & $\begin{array}{c}0.42 \\
(1.94)\end{array}$ & & $\begin{array}{c}1.08 \\
(3.92)\end{array}$ & & $\begin{array}{c}2.70 \\
(3.04)\end{array}$ \\
\hline $\begin{array}{l}\log \left(\text { rainfall }_{t-1}\right) \\
* \text { SC share }\end{array}$ & & & $\begin{array}{l}-4.22 \\
(4.19)\end{array}$ & & $\begin{array}{c}5.02 \\
(8.76)\end{array}$ & & $\begin{array}{c}4.43 \\
(8.52)\end{array}$ \\
\hline $\begin{array}{l}\log \left(\text { rainfall }_{t-1}\right) \\
* \text { Literacy share }\end{array}$ & & & $\begin{array}{c}-0.05^{* * *} \\
(0.02)\end{array}$ & & $\begin{array}{l}-0.02 \\
(0.03)\end{array}$ & & $\begin{array}{r}-0.05^{*} \\
(0.03)\end{array}$ \\
\hline $\begin{array}{l}\log \left(\text { rainfall }_{t-1}\right) \\
{ }^{*} \text { Forest area share }\end{array}$ & & & $\begin{array}{l}3.12^{*} \\
(1.75)\end{array}$ & & $\begin{array}{l}-1.44 \\
(3.58)\end{array}$ & & $\begin{array}{c}0.31 \\
(2.76)\end{array}$ \\
\hline $\begin{array}{l}\log \left(\text { rainfall }_{t-1}\right) \\
\text { * Population } \\
\text { density }\end{array}$ & & & $\begin{array}{c}0.002^{* *} \\
(0.001)\end{array}$ & & $\begin{array}{l}-0.001 \\
(0.002)\end{array}$ & & $\begin{array}{r}0.003^{* *} \\
(0.001)\end{array}$ \\
\hline Observations & 268 & 444 & 438 & 348 & 342 & 360 & 360 \\
\hline Districts & 123 & 74 & 73 & 58 & 57 & 60 & 60 \\
\hline Estimation & OLS & & & & Poisson & & \\
\hline $\begin{array}{l}\text { Notes: District-yeal } \\
\text { merged as describec } \\
\text { exception of } \log (\mathrm{M} \\
\text { fixed effects, state-y } \\
\text { at the district level }\end{array}$ & $\begin{array}{l}\text { vel observe } \\
\text { a the text. } \\
\text { ral value), } \\
* * \text { p }<0.01 \text {, }\end{array}$ & $\begin{array}{l}\mathrm{ns} \text {, coveri } \\
\mathrm{g} \text { (Mineral } \\
\text { interactio } \\
\text { and mine } \\
\mathrm{p}<0.05 \text {, }^{*}\end{array}$ & $\begin{array}{l}2005-2010 \\
\text { lue) is calc } \\
\text { variables a } \\
\text { dummy-ye } \\
<0.1 \text {. }\end{array}$ & $\begin{array}{l}2004-2006 \\
\text { lated as Lc } \\
\text { demeaned } \\
\text { ix fixed effe }\end{array}$ & $\begin{array}{l}\text { column 1). Di } \\
\text { Mineral value } \\
\text { All regressions } \\
\text { Standard er }\end{array}$ & $\begin{array}{l}\text { cts were } \\
\text { With } 1 \\
\text { lude dis } \\
\text { are clus }\end{array}$ & \\
\hline
\end{tabular}


Table 5: Motives of Violence against Civilians

\begin{tabular}{|c|c|c|c|}
\hline \multirow[b]{2}{*}{ Motive } & \multicolumn{3}{|c|}{ Civilian Casualties by Motive } \\
\hline & Number & Percent & $\begin{array}{c}\text { Percent } \\
\text { (excluding unspecified) }\end{array}$ \\
\hline \multicolumn{4}{|l|}{ Collaboration } \\
\hline Suspected police informers & 401 & 20.84 & 29.18 \\
\hline Surrendered Maoists & 23 & 1.67 & 1.67 \\
\hline $\begin{array}{l}\text { Members of political } \\
\text { parties/ political activity }\end{array}$ & 429 & 22.30 & 31.22 \\
\hline Members of vigilante groups & 98 & 5.09 & 7.13 \\
\hline (Collaboration total) & $(951)$ & $(49.90)$ & $(69.20)$ \\
\hline \multicolumn{4}{|l|}{ Other } \\
\hline Punishment for crimes & 25 & 1.30 & 1.82 \\
\hline Failure to pay levy & 31 & 1.61 & 2.26 \\
\hline Untargeted & 367 & 19.07 & 26.71 \\
\hline Unspectified & 550 & 28.59 & - \\
\hline$\underline{\text { Total }}$ & 1,924 & 100 & 100 \\
\hline
\end{tabular}


Table 6: Baseline Results per Type of Civilian Casualty

\begin{tabular}{|c|c|c|c|c|c|c|}
\hline & \multicolumn{2}{|c|}{$\begin{array}{c}\text { Civilian Casualties } \\
\text { (Collaboration) }\end{array}$} & \multicolumn{2}{|c|}{$\begin{array}{c}\text { Civilian Casualties } \\
\text { (Untargeted) }\end{array}$} & \multicolumn{2}{|c|}{$\begin{array}{c}\text { Security Forces } \\
\text { Casualties } \\
\text { (Selected Attacks) }\end{array}$} \\
\hline & (1) & $(2)$ & (3) & (4) & $(5)$ & (6) \\
\hline $\log \left(\operatorname{rainfall}_{t-1}\right)$ & $\begin{array}{c}-1.42^{* * *} \\
(0.51)\end{array}$ & $\begin{array}{c}-1.62^{* * *} \\
(0.48)\end{array}$ & $\begin{array}{c}1.34 \\
(1.18)\end{array}$ & $\begin{array}{c}1.05 \\
(1.67)\end{array}$ & $\begin{array}{c}0.12 \\
(0.67)\end{array}$ & $\begin{array}{c}0.10 \\
(0.82)\end{array}$ \\
\hline $\begin{array}{l}\log \left(\text { rainfall }_{t-1}\right) \\
* \log (\text { Mineral } \\
\text { value })\end{array}$ & $\begin{array}{c}0.08 \\
(0.08)\end{array}$ & $\begin{array}{c}0.01 \\
(0.08)\end{array}$ & $\begin{array}{c}-0.63^{* * *} \\
(0.29)\end{array}$ & $\begin{array}{c}-1.24^{* * *} \\
(0.46)\end{array}$ & $\begin{array}{c}-0.26^{* * *} \\
(0.09)\end{array}$ & $\begin{array}{l}-0.32^{*} \\
(0.18)\end{array}$ \\
\hline $\begin{array}{l}\log \left(\text { rainfall }_{t-1}\right) \\
* \text { ST share }\end{array}$ & & $\begin{array}{l}-0.84 \\
(2.85)\end{array}$ & & $\begin{array}{l}18.46^{*} \\
(9.96)\end{array}$ & & $\begin{array}{c}3.73 \\
(4.87)\end{array}$ \\
\hline $\begin{array}{l}\log \left(\text { rainfall }_{t-1}\right) \\
* \text { SC share }\end{array}$ & & $\begin{array}{c}-12.33^{*} \\
(7.22)\end{array}$ & & $\begin{array}{c}23.63 \\
(19.78)\end{array}$ & & $\begin{array}{c}4.75 \\
(10.29)\end{array}$ \\
\hline $\begin{array}{l}\log \left(\text { rainfall }_{t-1}\right) \\
* \text { Literacy share }\end{array}$ & & $\begin{array}{l}-0.04 \\
(0.03)\end{array}$ & & $\begin{array}{l}-0.05 \\
(0.08)\end{array}$ & & $\begin{array}{l}-0.01 \\
(0.03)\end{array}$ \\
\hline $\begin{array}{l}\log \left(\text { rainfall }_{t-1}\right) \\
* \text { Forest area share }\end{array}$ & & $\begin{array}{c}1.51 \\
(2.35)\end{array}$ & & $\begin{array}{c}7.59 \\
(7.86)\end{array}$ & & $\begin{array}{l}-3.05 \\
(4.36)\end{array}$ \\
\hline $\begin{array}{l}\log \left(\operatorname{rainfall}_{t-1}\right) \\
* \text { Population } \\
\text { density }\end{array}$ & & $\begin{array}{l}0.001^{*} \\
(0.001)\end{array}$ & & $\begin{array}{c}0.007 \\
(0.006)\end{array}$ & & $\begin{array}{l}-0.000 \\
(0.002)\end{array}$ \\
\hline Observations & 372 & 366 & 192 & 192 & 336 & 330 \\
\hline Districts & 62 & 61 & 32 & 32 & 56 & 55 \\
\hline Estimation & & & & & & \\
\hline
\end{tabular}

Notes: District-year level observations, covering 2005-2010. Districts were merged as described in the text. See text and table 5 for the coding of civilian casualties in columns (1)-(4). In columns (5) and (6), selected attacks on security forces exclude incidents with civilian casualties. With the exception of $\log ($ Mineral value), the interaction variables are demeaned. All regressions include district fixed effects, state-year fixed effects and mineral dummy-year fixed effects. Standard errors are clustered at the district level. *** $\mathrm{p}<0.01,{ }^{* *} \mathrm{p}<0.05,{ }^{*} \mathrm{p}<0.1$. 
Table 7: Robustness checks (interactions with rainfall)

\begin{tabular}{|c|c|c|c|c|c|c|c|}
\hline & \multicolumn{3}{|c|}{ Civilian Casualties } & \multicolumn{4}{|c|}{ Security Force Casualties } \\
\hline & (1) & $(2)$ & (3) & (4) & $(5)$ & (6) & $(7)$ \\
\hline $\log \left(\operatorname{rainfall} \operatorname{fl}_{t-1}\right)$ & $\begin{array}{c}-0.88^{* *} \\
(0.36)\end{array}$ & $\begin{array}{c}-1.13^{* * *} \\
(0.42)\end{array}$ & $\begin{array}{c}-0.96^{* * *} \\
(0.32)\end{array}$ & $\begin{array}{c}0.24 \\
(0.65)\end{array}$ & $\begin{array}{c}1.13 \\
(0.87)\end{array}$ & $\begin{array}{c}0.06 \\
(0.64)\end{array}$ & $\begin{array}{c}0.22 \\
(0.66)\end{array}$ \\
\hline $\begin{array}{l}\log \left(\operatorname{rainfall}_{t-1}\right) \\
{ }^{*} \log (\text { Mineral value })\end{array}$ & $\begin{array}{l}-0.09 \\
(0.06)\end{array}$ & $\begin{array}{c}0.02 \\
(0.05)\end{array}$ & & $\begin{array}{l}-0.30^{*} \\
(0.17)\end{array}$ & $\begin{array}{c}-0.28^{* * *} \\
(0.11)\end{array}$ & & $\begin{array}{c}-0.30 * * * \\
(0.11)\end{array}$ \\
\hline $\begin{array}{l}\log \left(\text { rainfall }_{t-1}\right) \\
{ }^{*} \log (\text { Mineral value })\end{array}$ & $\begin{array}{l}0.277 \\
(0.20)\end{array}$ & & & $\begin{array}{l}-0.09 \\
(0.43)\end{array}$ & & & \\
\hline $\begin{array}{l}\text { *ST share } \\
\log \left(\text { rainfall }_{t-1}\right) \\
\text { *ST Share }\end{array}$ & $\begin{array}{c}0.60 \\
(1.55)\end{array}$ & & & $\begin{array}{c}1.04 \\
(3.50)\end{array}$ & & & \\
\hline $\begin{array}{l}\log \left(\operatorname{rainfall}_{t-1}\right) \\
{ }^{*} \text { Flood prone }\end{array}$ & & $\begin{array}{c}0.55 \\
(0.51)\end{array}$ & & & $\begin{array}{c}0.35 \\
(0.85)\end{array}$ & & \\
\hline $\begin{array}{l}\log \left(\operatorname{rainfall}_{t-1}\right) \\
*^{*} \text { Mineral USGS }\end{array}$ & & & $\begin{array}{c}0.55 \\
(0.71)\end{array}$ & & & $\begin{array}{c}-1.92^{* *} \\
(0.91)\end{array}$ & \\
\hline $\begin{array}{l}\log \left(\operatorname{rainfall}_{t-1}\right) \\
{ }^{*} \text { Coal dummy }\end{array}$ & & & $\begin{array}{c}0.07 \\
(0.47)\end{array}$ & & & $\begin{array}{l}-0.98 \\
(1.17)\end{array}$ & \\
\hline $\begin{array}{l}\log \left(\text { rainfall }_{t-1}\right) \\
*(2005 \text { incidents with } \\
\text { Maoist fatalities })\end{array}$ & & & & & & & $\begin{array}{c}0.05 \\
(0.19)\end{array}$ \\
\hline Observations & 444 & 444 & 444 & 348 & 348 & 348 & 348 \\
\hline Districts & 74 & 74 & 74 & 58 & 58 & 58 & 58 \\
\hline Estimation & & & & Poisson & & & \\
\hline
\end{tabular}

Notes: District-year level observations observations, covering 2005-2010. Districts were merged as described in the text. Interaction variables are demeaned (except for mineral wealth and 2005 incidents). All regressions include district fixed effects, state-year fixed effects and mineral dummy-year fixed effects. Standard errors are clustered at the district level. ${ }^{* * *} \mathrm{p}<0.01,{ }^{* *} \mathrm{p}<0.05,{ }^{*} \mathrm{p}<0.1$. 
Table 8: Robustness checks (an alternative shock measure)

\begin{tabular}{|c|c|c|}
\hline & Civilian Casualties & Security Forces Casualties \\
\hline \multirow{2}{*}{ Dry year $_{t-1}$} & $0.41^{*}$ & -0.16 \\
\hline & $(0.24)$ & $(0.42)$ \\
\hline Dry year $r_{t-1}$ & -0.00 & $0.14^{* *}$ \\
\hline * Log(Mineral value) & $(0.05)$ & $(0.06)$ \\
\hline Observations & 444 & 342 \\
\hline Districts & 74 & 57 \\
\hline Estimation & & Poisson \\
\hline
\end{tabular}

Notes: District-year level observations observations, covering 2005-2010. Districts were merged as described in the text. Dry years are district-years that see less than $20 \%$ of the average district-level rainfall (2004-2010). All regressions include district fixed effects, state-year fixed effects and mineral dummy-year fixed effects. Standard errors are clustered at the district level. $* * * \mathrm{p}<0.01, * * \mathrm{p}<0.05, *$ $\mathrm{p}<0.1$. 
Table 9: OLS Reference (Results per Tertile)

Panel A

\begin{tabular}{|c|c|c|c|c|c|c|}
\hline \multirow[b]{2}{*}{ Mean } & \multicolumn{6}{|c|}{ Civilian Casualties (per 100,000 of the population) } \\
\hline & 0.26 & 0.014 & 0.05 & 0.72 & 0.34 & 0.20 \\
\hline \multirow{2}{*}{$\log \left(\operatorname{rainfall}_{t-1}\right)$} & $-0.26^{* *}$ & -0.01 & -0.08 & -0.89 & -0.22 & $-0.20 *$ \\
\hline & $(0.11)$ & $(0.03)$ & $(0.06)$ & $(0.60)$ & $(0.30)$ & $(0.11)$ \\
\hline $\log \left(\operatorname{rainfall}_{t-1}\right)$ & -0.30 & 0.05 & 0.08 & -0.72 & -0.34 & -0.07 \\
\hline * Mineral dummy & $(0.36)$ & $(0.04)$ & $(0.7)$ & $(1.59)$ & $(0.38)$ & $(0.15)$ \\
\hline Outliers omitted & No & No & No & No & Yes & Yes \\
\hline Tertiles & All & $1^{\text {st }}$ & $2^{n d}$ & $3^{r d}$ & $3^{r d}$ & $2^{n d} \& 3^{r d}$ \\
\hline Observations & 444 & 150 & 150 & 150 & 138 & 288 \\
\hline Districts & 74 & 24 & 25 & 25 & 23 & 48 \\
\hline Estimation & \multicolumn{6}{|c|}{ OLS } \\
\hline
\end{tabular}

Panel B

\begin{tabular}{|c|c|c|c|c|c|c|}
\hline \multirow[b]{2}{*}{ Mean } & \multicolumn{6}{|c|}{ Security Force Casualties (per 100,000 of the population) } \\
\hline & 0.33 & 0.01 & 0.04 & 0.91 & 0.40 & 0.21 \\
\hline $\log \left(\operatorname{rainfall}_{t-1}\right)$ & $\begin{array}{l}-0.13 \\
(0.18)\end{array}$ & $\begin{array}{c}0.01 \\
(0.01)\end{array}$ & $\begin{array}{c}0.02 \\
(0.04)\end{array}$ & $\begin{array}{l}-0.13 \\
(0.54)\end{array}$ & $\begin{array}{c}0.21 \\
(0.76)\end{array}$ & $\begin{array}{c}0.13 \\
(0.17)\end{array}$ \\
\hline $\begin{array}{l}\log \left(\operatorname{rainfall}_{t-1}\right) \\
* \text { Mineral dummy }\end{array}$ & $\begin{array}{l}-0.52 \\
(0.52)\end{array}$ & $\begin{array}{l}-0.00 \\
(0.03)\end{array}$ & $\begin{array}{l}-0.13 \\
(0.17)\end{array}$ & $\begin{array}{l}-2.27 \\
(1.44)\end{array}$ & $\begin{array}{l}-0.82 \\
(0.59)\end{array}$ & $\begin{array}{c}-0.48^{* *} \\
(0.22)\end{array}$ \\
\hline Outliers omitted & No & No & No & No & Yes & Yes \\
\hline Tertiles & All & $1^{s t}$ & $2^{n d}$ & $3^{r d}$ & $3^{r d}$ & $2^{n d} \& 3^{r d}$ \\
\hline Observations & 348 & 114 & 114 & 120 & 108 & 222 \\
\hline Districts & 58 & 19 & 19 & 20 & 18 & 37 \\
\hline Estimation & \multicolumn{6}{|c|}{ OLS } \\
\hline \multicolumn{7}{|c|}{$\begin{array}{l}\text { Notes: District-year level observations, } 2005-2010 \text {. Districts were merged as described in the } \\
\text { text. Included districts have at least one non-zero observation for the dependent variable. } \\
\text { Tertiles are based on the distribution of the total number of casualties over the sample period } \\
\text { divided by the district population and conditional on the district total exceeding zero. Outliers } \\
\text { are above the } 98 \text { th percentile of the distribution of the district casualty total. Reported means } \\
\text { are for the dependent variable of relevant subsample. All regressions include district fixed } \\
\text { effects, state-year fixed effects and mineral dummy-year fixed effects. Standard errors are } \\
\text { clustered at the district level. } * * * \mathrm{p}<0.01,{ }^{* *} \mathrm{p}<0.05,{ }^{*} \mathrm{p}<0.1 \text {. }\end{array}$} \\
\hline
\end{tabular}




\section{Table 10: OLS Reference (Baseline results)}

\begin{tabular}{|c|c|c|c|c|c|c|}
\hline & \multicolumn{2}{|c|}{$\log ($ Civilian Casualties +1$)$} & \multicolumn{2}{|c|}{$\log ($ Security Forces Casualties +1$)$} & \multicolumn{2}{|c|}{$\log ($ Maoist Casualties +1$)$} \\
\hline & (1) & $(2)$ & $(3)$ & $(4)$ & $(5)$ & (6) \\
\hline \multirow[t]{3}{*}{$\log \left(\operatorname{rainfall}_{t-1}\right)$} & $-0.38^{*}$ & $-0.45^{* *}$ & 0.16 & $0.43^{*}$ & -0.10 & -0.47 \\
\hline & $(0.21)$ & $(0.20)$ & $(0.23)$ & $(0.25)$ & $(0.35)$ & $(0.32)$ \\
\hline & {$[0.22]$} & {$[0.18]$} & {$[0.25]$} & {$[0.22]$} & {$[0.36]$} & {$[0.30]$} \\
\hline \multirow{3}{*}{$\begin{array}{l}\log \left(\operatorname{rainfall}_{t-1}\right) \\
* \text { Mineral dummy }\end{array}$} & -0.06 & 0.01 & $-0.77^{* *}$ & $-0.82^{*}$ & -0.54 & -0.34 \\
\hline & $(0.28)$ & $(0.30)$ & $(0.37)$ & $(0.48)$ & $(0.44)$ & $(0.40)$ \\
\hline & {$[0.23]$} & {$[0.22]$} & {$[0.35]$} & {$[0.40]$} & {$[0.37]$} & {$[0.33]$} \\
\hline & & 0.17 & & -0.64 & & -0.81 \\
\hline \multicolumn{7}{|l|}{ * Sched. Tribe } \\
\hline share & & $(1.25)$ & & $(1.58)$ & & $(1.79)$ \\
\hline $\log \left(\operatorname{rainfall}_{t-1}\right)$ & & -3.06 & & 0.07 & & -0.09 \\
\hline \multicolumn{7}{|l|}{ * Sched. Caste } \\
\hline share & & $(2.87)$ & & $(3.64)$ & & $(4.05)$ \\
\hline $\log \left(\operatorname{rainfall}_{t-1}\right)$ & & -0.01 & & 0.02 & & $-0.04^{* *}$ \\
\hline * Literacy share & & $(0.01)$ & & $(0.02)$ & & $(0.02)$ \\
\hline $\log \left(\operatorname{rainfall}_{t-1}\right)$ & & 1.09 & & -1.41 & & 1.49 \\
\hline * Forest area share & & $(1.05)$ & & $(1.65)$ & & $(1.61)$ \\
\hline $\log \left(\operatorname{rainfall}_{t-1}\right)$ & & 0.001 & & -0.001 & & 0.001 \\
\hline \multicolumn{7}{|l|}{ * Population } \\
\hline density & & $(0.001)$ & & $(0.001)$ & & $(0.001)$ \\
\hline Observations & 440 & 438 & 348 & 342 & 360 & 360 \\
\hline Districts & 74 & 73 & 58 & 57 & 60 & 60 \\
\hline Estimation & & & & OLS & & \\
\hline
\end{tabular}

Notes: District-year level observations, covering 2005-2010. Districts were merged as described in the text. Included districts have at least one non-zero observation for the dependent variable. With the exception of the mineral dummy, the interaction variables are demeaned. All regressions include district fixed effects, state-year fixed effects and mineral dummy-year fixed effects. Standard errors (s.e.) are clustered at the district level, standard errors [s.e.] are spatially clustered with linearily decreasing weights within a $250 \mathrm{~km}$ radius. For (s.e.): ${ }^{* * *} \mathrm{p}<0.01,{ }^{*} \mathrm{p}<0.05,{ }^{*} \mathrm{p}<0.1$. 